\title{
LIETUVOS KARININKAI DIPLOMATINĖJE TARNYBOJE TURKIJOJE, JUGOSLAVIJOJE IR BULGARIJOJE (1920-1922 M.)
}

\author{
Prof. dr. Sandra Grigaravičiūtè \\ Lietuvos edukologijos universitetas
}

\section{IVADAS}

1918-1922 m. Lietuvos diplomatineje tarnyboje karininkija vaidino svarbų vaidmenị. Pirmieji neoficialūs diplomatiniai atstovai buvo karininkai - gen. ltn. Pranas Vaiciuška (karinis atstovas Estijoje) ${ }^{1}$, kpt. Ladas Natkevičius (karinis atstovas Latvijoje ir Estijoje) ${ }^{2}$, kpt. Leopoldas Dymša (karinis atstovas Klaipedos krašte), kpt.* Bronius Blaveščiūnas (igaliotinis Turkijoje), mjr. ${ }^{* *}$ Stasys Zaskevičius (igaliotinis Ukrainoje ${ }^{3}$ ) dirbo Užsienio reikalų ministerijos (URM) ryšių karininkais, valdininkais ypatingiems reikalams (kpt. Stasys Girdvainis ${ }^{4}$, kpt. B. Blaveščiūnas ${ }^{5}$ ),

\footnotetext{
119200426 URM ịsakymas Nr. 80. LCVA, f. 383, ap. 2, b. 572, 1. 35; Lietuvos Respublikos karine diplomatija 1919-1940 m. Kariniai atstovai ir karo ataše. Kaunas, 2016, p. 8.

2 Lietuvos Respublikos karine diplomatija 1919-1940 m. Kariniai atstovai ir karo atašé. Kaunas, 2016, p. 8.

* Bronius Blaveščiūnas buvo Rusijos kariuomenès kapitonas, kaip ir kiti Komiteto Konstantinopolyje karininkai. Žr. 1a lentelę.

** Paskyrimo igaliotiniu Ukrainoje (vèliau - konsulu Petrograde) metu buvo majoras, karjerą baigè turèdamas brigados generolo laipsnị (suteiktas 1940 m.). Žr.: Lietuvos kariuomenés karininkai, 1918-1953. T. 8. Vilnius: Lietuvos nacionalinis muziejus, 2008, p. 300-301.

3 Grigaravičiūtè S. Lithuanian Consulates in Soviet Russia / the Soviet Union, 1921-1923. Vesture: avoti un cilveki. XXIII starptautisko zinätnisko lasijumu materiāli. Vēsture XVIII. Daugavpils Universitātes Akadēmiskais apgāds „Saule“, 2015, p. 58-74.

419201125 URM ịsakymas Nr. 131. LCVA, f. 383, ap. 2, b. 572, 1. 14; 1921 m. gruodžio mèn. (tikslesnès datos nèra) ịsakymas Nr. 230. LCVA, f. 383, ap. 2, b. 573, 1. 21; 19210926 URM įsakymas Nr. 183. LCVA, f. 383, ap. 2, b. 573, 1. 50; URM žinynas, 1933, p. 235.

51922 m. rugpjūčio mèn. (tikslesnès datos nèra) URM ịsakymas Nr. 307. LCVA, f. 383, ap. 2, b. $574,1.153$.
} 
specialiaisiais kurjeriais ir konfidencialiaisiais sekretoriais $\left(\operatorname{ltn} .{ }^{* * *}\right.$ Domas Steponavičius $^{6}$, kpt. S. Girdvainis ${ }^{7}$ ), komisijose (j. ltn. Zigmas Puzinauskas ${ }^{8}$ ), vyko $\mathfrak{i}$ specialias misijas (vyr. ltn. Juozas Macevičius). Lietuvos atstovybès prie Šventojo Sosto sekretoriai - vyr. ltn. Juozas Macevičius ${ }^{9}$, ltn. Kazys Graužinis ${ }^{10}$, kpt. S. Girdvainis ${ }^{11}$ - buvo karininkai. 1920-1921 m. nemažai Lietuvos, kaip ir Latvijos, karininkų perëjo dirbti $\mathfrak{i}$ diplomatinę tarnybą: vieni - karo ataš $\dot{e}^{12}$, kiti - konsulais ar konsulinių skyrių vadovais (mjr. S. Zaskevičius $^{13}$, gen. Itn. ${ }^{* * *}$ Teodoras Daukantas ${ }^{14}$, mjr. Povilas Žadeikis ${ }^{15}$,

${ }^{* * *}$ Karjerą kariuomenèje baigè turèdamas pulkininko laipsnị, suteiktą 1938 metais. Žr.: Lietuvos kariuomenés karininkai, 1918-1953. Vilnius: Lietuvos nacionalinis muziejus, 2007, t. 7, p. 193.

619220609 URM įsakymas Nr. 189. LCVA, f. 383, ap. 2, b. 574, 1. 253; 1922 m. balandžio (tikslesnès datos nèra) URM įsakymas Nr. 102. LCVA, f. 383, ap. 2, b. 574, 1. 325; 19220410 URM įsakymas Nr. 98. LCVA, f. 383, ap. 2, b. 574, 1. 329; 1922 m. vasario mèn. (tikslesnès datos nèra) URM įsakymas Nr. 33. LCVA, f. 383, ap. 2, b. 574, 1. 373.

719220202 URM ịsakymas Nr. 20. LCVA, f. 383, ap. 2, b. 574, 1. 381.

81922 m. gruodžio (tikslesnès datos nèra) URM ịsakymas Nr. 465. LCVA, f. 383, ap. 2, b. 574, 1. 14. Buvo 192108 01-1924 0111 URM komisijos narys nustatant Lietuvos ir Latvijos sieną. I t atsargą išèjo $1931 \mathrm{~m}$. Žr.: Lietuvos kariuomenes karininkai, 1918-1953. Vilnius: Lietuvos nacionalinis muziejus, 2006, t. 6, p. 197.

9 Kasparavičius A. Tarp politikos ir diplomatijos: Šventasis Sostas ir Lietuvos Respublika. Vilnius: LII leidykla, 2008, p. 76-77.

1019220121 URM įsakymas Nr. 7. LCVA, f. 383, ap. 2, b. 574, l. 392; URM žinynas, 1933, p. 235.

11 Užsienio reikaly ministerijos žinynas. Kaunas: URM, 1933, p. 235.

12 Lietuvos Respublikos kariné diplomatija 1919-1940 m. Kariniai atstovai ir karo atašè. Kaunas, 2016, p. 43.

1319220606 URM iqsakymas Nr. 185. LCVA, f. 383, ap. 2, b. 574, 1. 256.

**** 1936 m. - brg. gen. Žr.: Lietuvos kariuomenes karininkai, 1918-1953. Vilnius: Lietuvos nacionalinis muziejus, 2003, t. 3, p. 41.

${ }^{14}$ URM žinynas, 1933, p. 233.

151923 m. gruodžio mèn. (tikslesnès datos nẻra) ịsakymas Nr. 379. LCVA, f. 383, ap. 2, b. 575, 1. 18. URM įsakyme nurodytas majoro laipsnis, tačiau Lietuvos kariuomenès karininkų žinyne parašyta, kad P. Žadeikis $1923 \mathrm{~m}$. buvo plk. ltn. Žr.: Lietuvos kariuomenès karininkai, 1918-1953. Vilnius: Lietuvos nacionalinis muziejus, 2007, t. 8, p. 321. 
kpt. Leopoldas Dymša ${ }^{16}$, plk. Bruno Štencelis ${ }^{17}$, kpt. J. Urbšys), pasiuntiniais (kpt. J. Urbšys, plk. Kazys Škirpa, kpt. L. Natkevičius).

Karininkijos vaidmuo Lietuvos diplomatijoje (1918-1922 m.) iki šiol nèra atskleistas. Kuklaus tyrëjų dèmesio yra sulaukusi tik plk. Kazio Griniaus, kpt. L. Dymšos ir mjr. S. Zaskevičiaus 1919-1922 m. veikla ${ }^{18}$. 2016 m. pasirodęs Andriejaus Stoliarovo sudarytas informacinis leidinys „Lietuvos Respublikos karinė diplomatija 1919-1940 m. Kariniai atstovai ir karo atašë“ turètų paskatinti tyrimus šioje erdveje. 1921-1922-ieji buvo lietuvių karo pabėgėlių ir tremtinių grąžinimo iš buvusios Rusijos imperijos, Vakarų ir Vidurio Europos, Balkanų šalių, Turkijos metai. Karo pabėgèlių ir tremtinių grąžinimu rūpinosi specialiai tam paskirti igaliotiniai, turintys konsulinius igaliojimus. Dalis jų buvo Lietuvos karininkai ar karininko laipsnị Rusijos imperijoje igiję lietuviai.

Lietuvių komitetų Turkijoje, Jugoslavijoje ir Bulgarijoje 1920-1921 m. ir konsulinių atstovybių Konstantinopolyje ir Belgrade steigimo ir funkcionavimo proceso analizè svarbi tiek siekiant atskleisti atstovavimo Lietuvai Turkijoje, Jugoslavijoje ir Bulgarijoje ypatumus, tiek Lietuvos konsulinio tinklo užsienyje (Rusijoje, Ukrainoje, Azerbaidžane, Tolimųjų Rytų Respublikoje, Mandžiūrijoje ir kitur), kurto specialiai lietuvių karo pabėgèliams ir tremtiniams grąžinti, raidai nušviesti.

Tyrimo objektas - Lietuvos Respublikos piliečių komiteto Konstantinopolyje (toliau - Komitetas Konstantinopolyje), Lietuvos Respublikos piliečių tarybos Belgrade, Lietuvių komiteto Sofijoje įsteigimą lėmę veiksniai ir motyvai, personalas ir jo veikla bei pirmųjų dviejų komitetų

16 Grigaravičiūtė S. Lietuvos atstovybė Klaipėdos krašte. Mažosios Lietuvos enciklopedija. Vilnius, 2003, t. 2, p. 631-632; Grigaravičiūtė S. Lietuvos generalinis konsulatas Karaliaučiuje. Mažosios Lietuvos enciklopedija. Vilnius, 2003, t. 2, p. 279-281.

17 Raudonius F. Lietuvos konsulatai Vienoje 1930-1938 m. Bakalauro darbas. 2006. Saugomas LEU IF IDC kabinete. Bruno Štencelis - pulkininkas nuo 1925 m. Žr.: Lietuvos kariuomenés karininkai, 1918-1953. Vilnius: Lietuvos nacionalinis muziejus, 2007, t. 7, p. 344.

18 Gaigalaitė A. Lietuva Paryžiuje 1919 metais. Kaunas: Šviesa, 1999, p. 131-135; Grigaravičiūtẻ S. Lietuvos generalinis konsulatas Karaliaučiuje. Mažosios Lietuvos enciklopedija. Vilnius, 2003, t. 2, p. 279-281; Grigaravičiūtè S. Lithuanian Consulates in Soviet Russia / the Soviet Union, 1921-1923. Vesture: avoti un cilveki. XXIII starptautisko zinātnisko lasījumu materiāli. Vēsture XVIII. Daugavpils Universitātes Akadēmiskais apgāds "Saule“, 2015, p. 58-74. 
(tarybų) transformacija $\mathfrak{i}$ konsulines atstovybes, taip pat Lietuvos vyriausybès igaliotinių - kpt. B. Blaveščiūno Turkijoje ir kpt. Leonardo Lippingo Jugoslavijoje - veikla, konsulinių atstovybių Konstantinopolyje ir Belgrade funkcionavimo ypatumai ir uždarymo aplinkybès. Ypatingas straipsnio autorès dèmesys skirtas vyr. ltn. J. Macevičiaus ir Vaclovo Sidzikausko misijų tikslų ir rezultatų analizei. Tyrimas atliktas naudojant analizès, lyginimo, aprašomajji, šaltinių ir literatūros gretinimo metodus. Apdorojant pirminius šaltinius, ypač prancūzų ir anglų kalbomis, taikytas loginis-analitinis metodas (atlikta turinio ir informacijos prasminè analizè).

Tyrimas apima laikotarpi nuo 1920 m. lapkričio 1 d. - Komiteto Konstantinopolyje įsteigimo - iki $1922 \mathrm{~m}$. kovo $31 \mathrm{~d}$. - Lietuvos vyriausybès igaliotinio Turkijoje atšaukimo ir Lietuvos konsulinès atstovybès Turkijoje uždarymo. Lietuvių komitetų, vèliau - konsulinių atstovybių veikla Turkijoje, Jugoslavijoje ir Bulgarijoje, remiantis archyvinių šaltinių analize, išskiriama ị du laikotarpius. Pirmasis - nuo $1920 \mathrm{~m}$. lapkričio $1 \mathrm{~d}$. iki 1921 m. vasario 9 d., t. y. nuo Komiteto Konstantinopolyje įsteigimo iki jo transformacijos ị Lietuvos konsulinę atstovybę Turkijoje (Lietuvos vyriausybès igaliotinio instituciją) - Komiteto Konstantinopolyje veiklos laikotarpis. Tuo metu dar nebuvo ịsteigta Lietuvos Respublikos piliečiu taryba Belgrade ir Lietuvių komitetas Sofijoje. Antrasis - nuo $1921 \mathrm{~m}$. vasario 9 d. iki $1922 \mathrm{~m}$. kovo 31 d., t. y. nuo igaliojimų kpt. B. Blaveščiūnui suteikimo iki jo atšaukimo iš Lietuvos vyriausybès igaliotinio pareigu - Lietuvos vyriausybés igaliotinio veiklos laikotarpis. Tuo metu jau buvo issteigta ir veikè Lietuvos Respublikos piliečių taryba Belgrade ir Lietuvių komitetas Sofijoje, organai, pavaldūs Lietuvos vyriausybès igaliotiniui Konstantinopolyje. Lietuvos Respublikos piliečių taryba Belgrade $1921 \mathrm{~m}$. gegužès $7 \mathrm{~d}$. buvo de facto (nes kpt. B. Blaveščiūnas neturèjo Lietuvos vyriausybès igaliojimų skirti igaliotinius, nors tuo metu veikusio Konsulinio statuto nuostatos konsului ir leido tai daryti), o $1921 \mathrm{~m}$. birželio $28 \mathrm{~d}$. - de jure (nes vyr. ltn. J. Macevičius turejjo igaliojimus skirti igaliotinius) transformuota $\mathfrak{i}$ Lietuvos vyriausybès igaliotinio instituciją. Antrasis laikotarpis skirstytinas i du etapus - iki vyr. ltn. Juozo Macevičiaus misijos ir po jos, t. y. nuo $1921 \mathrm{~m}$. vasario 9 d. iki $1921 \mathrm{~m}$. birželio ir nuo 1921 m. birželio iki 1922 m. kovo 31 d. Tiksliau datuoti sudètinga, 
nes vyr. ltn. J. Macevičiaus misija truko 5 mènesius (nuo 1921 m. gegužès iki rugsèjo įskaitytinai).

Tyrimo tikslas - išanalizuoti lietuvių komitetų (tarybų) ir konsulinių atstovybių Turkijoje, Jugoslavijoje ir Bulgarijoje steigimo ir funkcionavimo procesą $1920 \mathrm{~m}$. lapkričio $1 \mathrm{~d}$ - $-1922 \mathrm{~m}$. kovo $31 \mathrm{~d}$., ypatingą dèmesi skiriant komitetų pirmininkų ir igaliotinių - karininkų - veiklai. Siekiant tikslo: 1) vertinami šaltiniai ir istoriografija, nustatomos tyrimo problemos; 2) tiriamos Komiteto Konstantinopolyje įkūrimo aplinkybès, funkcijos ir jame dirbusių asmenų veikla; 3 ) analizuojama Lietuvos konsulinių atstovų - kpt. B. Blaveščiūno Turkijoje ir kpt. L. Lippingo Jugoslavijoje veikla $1921 \mathrm{~m}$. vasario $9 \mathrm{~d}$. - $1922 \mathrm{~m}$. kovo $31 \mathrm{~d}$., išskiriant laikotarpius iki ir po vyr. ltn. J. Macevičiaus misijos; 4) nagrinèjama vyr. ltn. Juozo Macevičiaus misija Jugoslavijoje ir Turkijoje (1921 m. gegužè-rugsẻjis) ir vertinami jos rezultatai; 5) analizuojama V. Sidzikausko misija Balkanų šalyse ir Turkijoje (1922 m. kovo 12 -31 d.) ir atskleidžiamos konsulinių atstovybių uždarymo aplinkybès.

Straipsnyje vartojamų sąvokų („repatriacija“, „reevakuacija“, „pabe்gèlis“, „,belaisvis“, „tremtinys“, „igaliotinis“, „gudas“), pavardžių (Blaveščiūnas, Geselsonas), vietovardžių (Konstantinopolis, Tiflisas) turinys ir rašyba paaiškinti ịvade (žr. toliau įvade), todèl tekste jų samprata aptarinèjama nebus.

Repatriacija straipsnio autorès suvokiama kaip Lietuvos piliečių (tremtinių, belaisvių, pabėgèlių) grịžimas ị tėvynę ${ }^{19}$, reevakuacija - piliečių grąžinimas ị jų gyvenamąją vietą, pasibaigus evakuacijai (turimi omenyje evakuotieji per Pirmajji pasaulinị karą $)^{20}$, pabègèlis - savo gimtąj ł kraštą palikęs žmogus ${ }^{21}$, belaisvis - ì nelaisvę patekęs ginkluotųjų pajègų karys, savanoris, pasipriešinimo judejjimo dalyvis, partizanas, sukilèlis $^{22}$, tremtinys - žmogus, privestas išvykti ị kitą kraštą ${ }^{23}$.

\footnotetext{
19 Repatriacija. Tarptautinių žodžių žodynas. Vilnius: VER, 1985, p. 423.

20 Reevakuacija. Tarptautinių žodžių žodynas. Vilnius: VER, 1985, p. 417.

21 Pabègèlis. Dabartinés lietuvių kalbos žodynas. Vilnius: Mintis, 1972, p. 471.

22 Tamošiūnienė M. Tarp politinio ịrankio ir aukos: karo belaisviai Lietuvos Respublikos politikoje 1919-1923 m. Vilnius, 2014, p. 12.

23 Tremtinys: http://www.lkz.lt/startas.htm [prisijungta 2016-08-12]. Tremtinio sąvoka buvo konkrečiau apibrèžta to meto tremtinių grąžinimo sutartyse, pvz., Tremtinių grą-
} 
Vardai ir pavardès, paminèti dokumentuose prancūzų kalba, rašomi dviem kalbomis: pirma - lietuvių, po to skliaustuose - prancūzų. Kpt. Broniaus Blaveščiūno pavardès rašyba šaltiniuose ịvairuoja. Neretai rašoma „Blavieščiūnas“, o tekstuose prancūzų kalba - „Blaveshtchunas“, „Blaviestchounasse“. Tekste bus rašoma „Blaveščiūnas“. Analogiška situacija ir su Salomono Geselsono pavarde. Vienur ji rašoma „Guesselson“, kitur - „Hesselsone“. Tekste bus vartojama „Geselson“ forma. Prie karininko pavardès bus nurodomas karinis laipsnis,

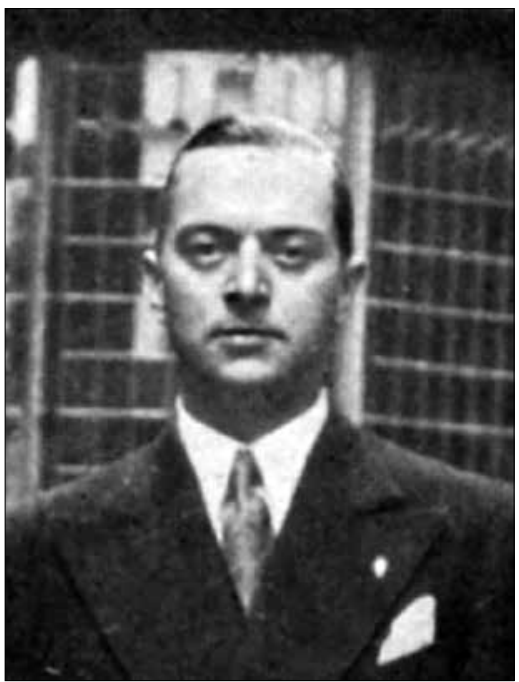

Kapitonas B. Blaveščiūnas kurị jis turejjo paskyrimo ị pareigas ir jų ejjimo laikotarpiu. Stambulo vardu miestas pavadintas 1930 metais, todèl tekste vartojamas oficialus to meto miesto pavadinimas - Konstantinopolis. Tiflisas pavadintas Tbilisiu 1936 metais, todèl tekste vartojamas senasis miesto pavadinimas.

Igaliotinis - Lietuvos Respublikos vyriausybès paskirtas atstovas arba Lietuvos Respublikos vyriausybès specialaus igaliotinio paskirtas atstovas, turintis konsulinius igaliojimus. Igaliotinis buvo skiriamas specia-

žinimo sutartyje tarp Lietuvos ir Rusijos 2-ame straipsnyje teigiama, kad „tremtiniais yra skaitomi asmenys, kurie pirmiau yra gyvenę vienos susitariančios šalies teritorijoje, o dabar yra antrosios šalies teritorijoje ir kurie 1914-1917 m. pasaulinio karo laiku patys apleido priešininko užimtas arba gresiamas sritis arba kurie buvo ištremti iš tų sričių Rusijos caro arba civilinès valdžios ịsakymu“. Tremtiniais buvo laikomi ir Pirmojo pasaulinio karo šauktiniai („imtiniai“), kurie gyveno vienos susitariančios šalies teritorijoje ir šios sutarties pasirašymo metu atsirado antrosios šalies teritorijoje. Žr.: Tremtinių grąžinimo sutartis tarp Lietuvos ir Rusijos. Vyriausybès žinios, 192108 03, Nr. 42, p. 1. Ką laikyti tremtiniais, diskutuota ir Kaukazo lietuvių atstovų suvažiavime 1917 m. gruodžio 27-30 d. Buvo nuspręsta tremtiniais laikyti ir prieš karą Kaukaze apsigyvenusius lietuvius, nes jie vyko svetur ne savo noru, „negalèdami tèvynejje surasti pragyvenimo šaltinių“. Žr.: Aničas J. Petras Vileišis, 1851-1926. 2-as papild. ir patais. leid. Vilnius: Alma littera, 2001, p. 424. 


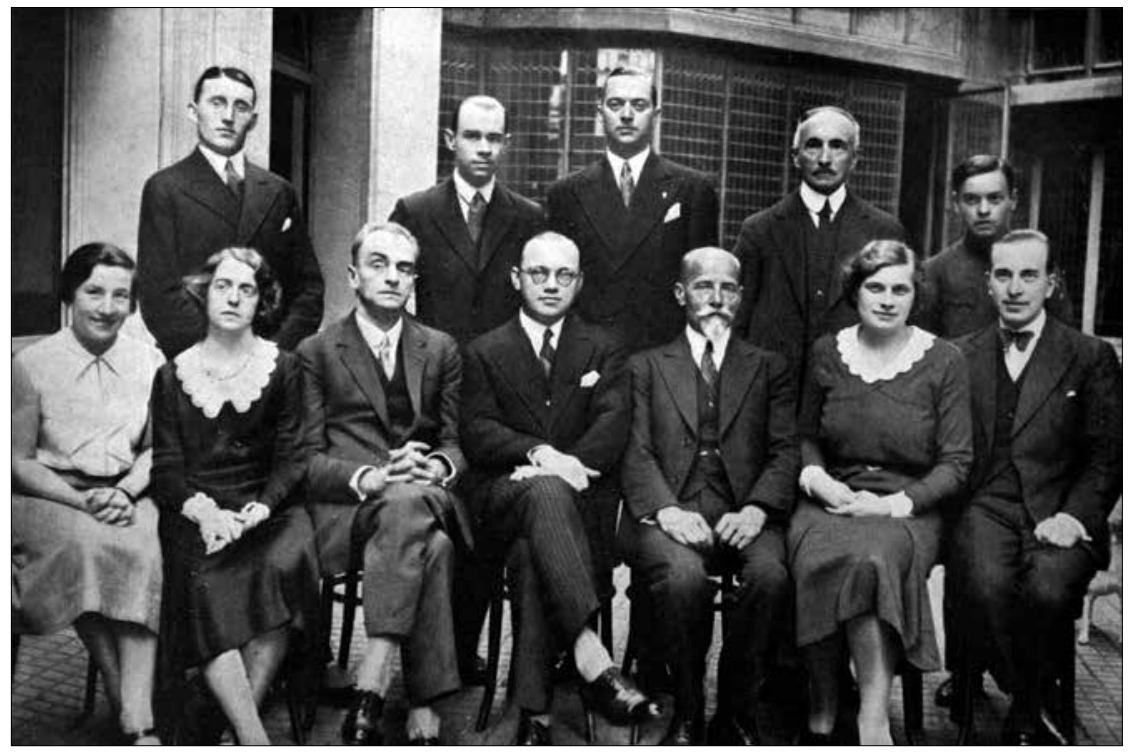

Pasiuntinybès Paryžiuje personalas, 2 eilèje 3-ias iš kairès - B. Blaveščiūnas

liai misijai atlikti, pvz., padèti pargabenti karo pabègèlius, tremtinius ar belaisvius $^{24}$. Igaliotinių išduodamas dokumentas - sertifikatas (pranc. k. certificat) - tekste vadinamas „liudijimu“, „pažymèjimu“. Abi sąvokos vartojamos sinonimiškai. Sąvoka „gudai“ vartojama tekste kaip sąvokos „baltarusiai“ sinonimas ${ }^{25}$.

Sąvoka „lietuviai“ tekste turi keletą prasmių. Pirmoji reiškia Lietuvos piliečius (Lietuvos Respublikos piliečius), galinčius dokumentais pagrịsti savo „lietuvišką kilmę“ (jie turèjo: caro valdžios ịstaigų Lietuvoje 1913-1915 m. išduotus pasus, rekvizicijos lapus ar turto aprašymus; Tatjanos ar kitų komitetų (įstaigų) dokumentus tremtiniams šelpti,

24 Mūsų tremtinių ir jų turtų grąžinimas iš Sovietų Rusų (pašnekesys su S. Šimkum). Lietuva, 192103 12, Nr. 56, p. 1; Grigaravičiūtè S. Lietuvos igaliotiniai, jų statusas ir funkcijos 1918-1922 metais. Pranešimas skaitytas nacionalinejje mokslinèje konferencijoje „Lietuvos diplomatija ir diplomatai XV-XXI a. (I)“ (LEU, Vilnius) 20151204.

25 Gimžauskas E. Baltarusių veiksnys formuojantis Lietuvos valstybei 1915-1923 m. Vilnius: LLI leidykla, 2003, p. 5. 
1914-1917 m. liudijimus ${ }^{26}$. Straipsnio autorès nagrinejjamu atveju lietuviai turèjo Lietuvių komiteto Kryme (būtent šio komiteto nariai ịejo ì Komiteto Konstantinopolyje sudètị ${ }^{27}$ ) ir Lietuvių komiteto Sevastopolyje išduotus liudijimus arba iš viso jokių asmens dokumentų neturëjo, bet buvo „nenustoję lietuvių tautinių požymių“28 (gerai mokejo lietuvių kalbą - aut. past.). Iš jų nebuvo reikalaujama dokumentais ịrodyti lietuviškos kilmès ${ }^{29}$. Lietuviais tekste taip pat vadinami tie, kurie turejo teisę (pagal Lietuvos pilietybės įstatymą) optuoti Lietuvos pilietybę. Kiek kitokia sąvokos „lietuviai“ samprata yra oficialiame Lietuvių komiteto Sofijoje pavadinime. Sąvoka „lietuviai“ komiteto pavadinime jokiu būdu nereiškia, kad jị sudarè lietuviai pirmąja šio žodžio prasme. Komitetas taip pavadintas, kad galètų išduoti pasus ir liudijimus vykstantiems ị Lietuvą asmenims (dažniausiai gen. ltn. P. Vrangelio kariuomenès karininkams aut. past.) ir iš to gauti pelną ${ }^{30}$.

2619220512 M. Čepo pranešimas užsienio reikalų ministrui V. Jurgučiui. LCVA, f. 383, ap. 4, b. 49, 1. 48-55. Nuo $1921 \mathrm{~m}$. lapkričio 22 d. norint pagrịsti „lietuvišką kilmę“ reikejo turèti „senuosius rusų pasus“, Oberosto (vok. Ober Ost) pasus, „rusų laikų bendras gyventojų sąrašų knygas“, gimimo ar jungtuvių metrikus. Šios nuostatos galiojo išsiimantiems pasą iki $1922 \mathrm{~m}$. kovo $31 \mathrm{~d}$. Žr.: Pasų ịstatų papildymo ir pakeitimo įstatymas (priimtas 1921 m. lapkričio 22 d.). Vyriausybés žinios, 192112 20, Nr. 75, p. 1.

$271922 \mathrm{~m}$. balandžio (pranešime data nenurodyta) V. Sidzikausko pranešimas URM apie misiją Turkijoje, Jugoslavijoje ir Bulgarijoje. LCVA, f. 383, ap. 7, b. 257, 1. 7, 11 a.

28 URM Vladas Jurgutis labai prašè, išduodant Lietuvos pasus, kreipti dèmesị ị lietuvių kalbos mokẻjimą ir ryšių su Lietuva palaikymą: „[P]asai gali būti išduoti tik lietuviams, nenutraukusiems gyvų ryšių ir gerai mokantiems lietuviškai. Kai dèl visų kitų, tai iš jų reikia pareikalauti tiksliai surašytą anketos lapą pagal pavyzdị ir atsiųsti ị URM patikrinti žinių. Kol nebus patikrinti duomenys URM, tam asmeniui galima išduoti laikiną liudijimą, kad jo pilietybės klausimais konsulato susirašyta su URM. Tą pačią taisyklę reikia taikyti tiems asmenims, kurie jau yra gavę pasus iš kurios nors lietuvių įstaigos buvusioj Rusijos imperijoj, kurios nebuvo visai arba pakankamai legalizuotos mūsų Vyriausybès.“ Žr.: 19220610 V. Jurgučio laiškas Lietuvos Respublikos igaliotiniui Vladivostoke K. Jociui. LCVA, f. 383, ap. 4, b. 49, 1. 29.

2919220418 Lietuvos atstovybès Tarybų Rusuose patarèjo raštas J. Grigaliūnui. LCVA, f. 383, ap. 4, b. 49, 1. 159. Ši nuostata negaliojo Stolypino reformos laikotarpiu persikèlusių i Omsko guberniją lietuvių kaimų lietuviams. Žr.: 19220404 J. Grigaliūno pranešimas Lietuvos atstovybei Tarybų Rusuose. LCVA, f. 383, ap. 4, b. 49, 1. 160-161.

$301922 \mathrm{~m}$. balandžio (pranešime data nenurodyta) V. Sidzikausko pranešimas URM apie misiją Turkijoje, Jugoslavijoje ir Bulgarijoje. LCVA, f. 383, ap. 7, b. 257, 1. 7-8. 
Sąvoka „Lietuvos Respublikos pilietis“ komiteto ir tarybos pavadinime taip pat nereiškè, kad komitetą sudaro vien Lietuvos Respublikos piliečiai. Pavadinimas greičiau turèjo būti priemonè Lietuvos vyriausybès pripažinimui ir paramai gauti, orientyras lietuviams pirmąja šio žodžio prasme, siekiantiems grịžti $\mathfrak{i}$ tèvynę ir norintiems gauti kelionės dokumentus. Taip pat tai turèjo būti žinia Antantès aukštiesiems komisarams ir kitiems diplomatams, reziduojantiems Konstantinopolyje, kad Komitetas Konstantinopolyje ir Lietuvos Respublikos piliečių taryba Belgrade yra oficialios ịstaigos ir jų išduodamais dokumentais galima pasitikèti.

Sąvoka „Lietuvos pilietis“ buvo vartojama jau 1918 m. gegužès-lapkričio mèn. lietuvių tautinių tarybų, susikūrusių Rusijos imperijoje susidariusių naujų valstybių (Gruzijos, Tarybų Rusijos, Ukrainos) teritorijose, išduodamuose dokumentuose (kreipimuose it priimančiosios šalies vyriausybę, liudijimuose). 1918 m. gegužès 29 d. Kaukazo lietuvių tarybos kreipimesi ị Gruzijos Demokratinès Respublikos vyriausybę teigiama, kad Kaukazo lietuvių taryba laikinai (iki bus užmegzti diplomatiniai santykiai - aut. past.) apsiima ginti Lietuvos piliečius („граждан Литвы“), gyvenančius Gruzijos teritorijoje ${ }^{31}$.

1918 m. liepos 9 d. Klemensui Matusevičiui išduotame Lietuvių vyriausios tarybos Ukrainoje liudijime teigiama: „[S]ulig Lietuvos Tarybos paskelbtos 22-23 kovo mèn. $1918 \mathrm{~m}$. Lietuvos nepriklausomybès ir visiems priverstinos tarptautinès teisès - šiojo Lietuvos piliečio asmuo, butas ir turtas yra neliečiami; jo suemimas, kratos ir turto rekvizicijos tegalimos Lietuvių Tarybos igaliotiniui dalyvaujant. “"32

1918 m. lapkričio 15 d. Lietuvos Valstybès Tarybos atstovo Petrograde išduotame liudijime Enrikui-Miroslavui Medekšai parašyta: „[P]agal Lietuvos Tarybos atstovybejje parodytų dokumentų tikrai yra Lietuvos pilietis $<\ldots>^{\text {"33 }}$ Laikinajame Lietuvos pilietybès ịstatyme, priimtame

31 Aničas J. Petras Vileišis, 1851-1926. 2-asis patais. ir papild. leid. Vilnius: Alma littera, 2001, p. 426. Išsamiau žr.: Grigaravičiūtė S. Diplomacy of the Council of Lithuania (September 1917-May 1920). Vesture: avoti un cilveki. XXV starptautisko zinatnisko lasijumu materiali. Vesture XIX. Daugavpils Universitates Akademiskais apgads „Saule“, 2016, p. 90-104.

321918 m. liepos 9 d. Klemensui Matusevičiui išduotas Lietuvių vyriausios tarybos Ukrainoje liudijimas. LCVA, f. 928, ap. 28, b. 3, 1. 246a.

331918 m. lapkričio 15 d. Enrikui-Miroslavui Medekšai Lietuvos valstybės tarybos atsto- 
1919 m. sausio 9 d., buvo apibrèžta, kas „laikomi Lietuvos piliečiais“34. Lietuvos piliečiais laikomi asmenys, kurie iki 1914 m. ne mažiau kaip 10 metų gyveno Lietuvoje ir turejjo arba turto, arba nuolatinị darbą ${ }^{35}$, taigi tremtiniams optuoti Lietuvos pilietybès nereikejo ${ }^{36}$.

Tarybų Rusijoje (ir jos kompetencijai priklausiusioje Rusijos imperijos teritorijoje) likusių asmenų Lietuvos pilietybès optavimas buvo reglamentuotas $1920 \mathrm{~m}$. liepos $12 \mathrm{~d}$. Lietuvos ir Tarybų Rusijos taikos sutarties VI straipsnyje. Jame pakartotos Laikinojo Lietuvos pilietybės įstatymo 1 paragrafo nuostatos ir išdèstytos papildomos, susijusios su tremtinių grịžimu ir Lietuvos pilietybės optacija ${ }^{37}$. Skiriant kpt. B. Blaveščiūną Lietuvos Respublikos igaliotiniu Konstantinopolyje $1921 \mathrm{~m}$. vasario 9 d. buvo nurodyta, kad Lietuvos piliečiais galima laikyti asmenis, gimusius Lietuvoje, ir tuos, kurie gyveno Lietuvoje 10 metų prieš karą, išskyrus Rusijos tarnautojus (valdininkus). Lietuvos teritorija prašoma laikyti senąją Kau-

vo Petrapily išduotas liudijimas. LCVA, f. 928, ap. 28, b. 3, 1. 27.

341 paragrafe teigiama, kad Lietuvos piliečiais laikomi asmenys, kurių tèvai ir seneliai gyveno ir jie patys gyvena Lietuvoje, jų vaikai (net jei Lietuvoje ir negyveno, bet grịžo ị ją gyventi), asmenys, kurie iki 1914 m. ne mažiau kaip 10 metų gyveno Lietuvoje ir turejjo arba turto, arba nuolatinị darbą, Lietuvos piliečio vaikai, žmona ar našlè, netekejjusios Lietuvos pilietės vaikai (jei jų nepripažino užsienietis tèvas), užsieniečiai, tapę Lietuvos piliečiais. Žr.: Laikinas ịstatymas apie Lietuvos pilietybę. Laikinosios vyriausybès žinios, 191901 16, Nr. 2-3, p. 5.

35 Laikinas įstatymas apie Lietuvos pilietybę. Laikinosios vyriausybès žinios, 19190116 , Nr. 2-3, p. 5.

36 Sudarant tremtinių sąrašus Rusijoje buvo svarstoma, ką daryti su 1914-1918 m. mobilizuotais „pačioj Lietuvoj piliečiais“ <...> Nors jie nepaminèti tremtinių skaičiuje, kaip, pvz., karo belaisviai, bet teisingai, beje, ir jie pridera skirti prie tremtinių. $<\ldots>$ taip manydamas ir tuos mobilizuotuosius dèsiu ị tremtinių sąrašą“. Žr. 19220420 M. Čepo pranešimas Lietuvos atstovybès Tarybų Rusuose Tremtinių skyriui. LCVA, f. 383, ap. 4, b. 49, 1. 71-72. 37 Lietuvos Taikos sutartis su Rusija. Vyriausybès žinios, 192011 30, Nr. 53, p. 4-5. Iš Sibiro ir Tolimųjų Rytų Respublikos grịžtantys lietuviai buvo suskirstyti ị tris kategorijas lietuvius tremtinius, lietuvius optantus ir lietuvius kandidatus ị optantus. „Tautinis pasas“ arba liudijimas buvo išduodamas tokiam tremtiniui, optantui arba kandidatui ị optantus, kuris atitiko Lietuvos atstovybès Tarybų Rusuose instrukcijoje išdèstytus kriterijus, t. y. turejjo: 1) caro valdžios ịstaigų Lietuvoje 1913-1915 m. išduotus pasus, rekvizicijos lapus ar turto aprašymą; 2) Tatjanos ar kitų komitetų-įstaigų dokumentus tremtiniams šelpti, 1914-1917 m. liudijimus; 3) Lietuvos Respublikos VRM liudijimus. Žr. 19220512 M. Čepo pranešimas užsienio reikalų ministrui V. Jurgučiui. LCVA, f. 383, ap. 4, b. 49, 1. $48-55$. 
no guberniją ir Suvalkų guberniją be Suvalkų ir Augustavo apskričių, taip pat Vilniaus guberniją be Dysnos ir Vileikos apskričių ${ }^{38}$. Vyr. ltn. J. Macevičiui buvo nurodyta, nustatant Lietuvos piliečių skaičių URM, griežtai laikytis „Lietuvos pilietybės įstatymo“ ir vadovautis „ypatingomis instrukcijomis“, kurios buvo duotos Lietuvos atstovybèms užsienyje ${ }^{39}$.

\section{1. ŠALTINIAI IR ISTORIOGRAFIJA}

\subsection{Istoriografija}

Apie lietuvius, tarnavusius gen. ltn. Antono Denikino ir adm. Aleksandro Kolčako armijose ir joms pralaimejus grižtančius i Lietuvą per Turkiją, Jugoslaviją, Bulgariją ir kitas šalis 1919 m., viena pirmųjų yra užsiminusi istorikè Aldona Gaigalaitè monografijoje „Lietuva Paryžiuje 1919 metais " ${ }^{40}$. Tačiau istorikès tyrimo objektu tapo tik tie lietuviai, kurie užsiregistravo Pareivių komisijoje, veikusioje prie Lietuvos delegacijos Paryžiuje (vadovas K. Grinius), ir grịžo per Prancūziją (tiksliau - jos uostus). Apie lietuvius (pabègèlius, belaisvius, tremtinius), grị̌ztančius iš Turkijos, Jugoslavijos, Bulgarijos per Vokietiją 1921 m., nerašoma, nes tyrimo chronologinè riba - 1919 m. pabaiga. Milenos Tamošiūnienès atliktas tyrimas atskleide lietuvių karo belaisvių grąžinimo iš Vokietijos, Prancūzijos, Belgijos organizavimo ypatumus, jame dalyvavusias institucijas ir jų kompetenciją, tgaliotinių darbo sąlygas ${ }^{41}$, tačiau apie belaisvių grąžinimą iš Turkijos ir Balkanų šalių 1921-1922 m. jame neužsiminta.

Petro Vileišio kelionè ì Lietuvą per Konstantinopolị, Sofiją ir Belgradą iš Tifliso aprašyta Jono Aničo monografijoje. Joje, remiantis informacija

3819210209 P. Klimo telegrama ị Konstantinopolị B. Blaveščiūnui. LCVA, f. 383, ap. 7, b. 214,1 . 53. Tas pat prancūzų kalba. LCVA, f. 383, ap. 7, b. 214, 1. 60.

3919210502 B. K. Balučio duota instrukcija J. Macevičiui. LCVA, f. 383, ap. 7, b. 214, 1. 18.

40 Gaigalaitè A. Lietuva Paryžiuje 1919 metais. Kaunas: Šviesa, 1999, p. 131-135.

41 Tamošiūnienė M. Tarp politinio ịrankio ir aukos: karo belaisviai Lietuvos Respublikos politikoje 1919-1923 m. Vilnius, 2014. 167 p. p. 31-49. 
dienraštyje „Lietuva“, teigiama, kad lietuvių Konstantinopolyje atsirado su gen. ltn. Piotro Vrangelio kariuomenès likučiais, jie ir sudarè „Pabėgèlių tarybą, kuri rūpinasi jų grịžimu ị tèvynę “42. Nei apie „Pabègèlių tarybos“ pirmininką, nei apie jos narius ir jų veiklą neužsiminta. Tikslesnès žinios apie kpt. B. Blaveščiūno karjerą Lietuvos užsienio reikalų ministerijoje pateiktos 1933 m. URM žinyne. Jame nurodytos tikslios jo paskyrimo ir atšaukimo datos, padedančios patikslinti archyvinę informaciją ${ }^{43}$. Vyr. ltn. Juozo Macevičiaus misija Balkanų šalyse - „gelbèti Didžiojo karo metais ten nublokštų lietuvių tremtinių" - paminèta Algimanto Kasparavičiaus monografijoje, aptariant Lietuvos atstovybès prie Šventojo Sosto finansines problemas. Straipsnio autorès tyrimui yra svarbūs A. Kasparavičiaus paminèti faktai apie Užsienio reikalų ministerijos J. Macevičiui išmokètą algą ir dienpinigius (6940 Turkijos lirų) ir jo misijos trukmę (5 mèn.) ${ }^{44}$. Apie Juozą Macevičių, vèliau tapusị Lietuvos reikalų patikètiniu prie Šventojo Sosto, kalbama kaip apie dailininką, neminimas jo išsilavinimas ir patirtis karineje srityje. Naudingos informacijos tyrimui apie vyr. ltn. Juozą Macevičių yra leidinyje „Lietuvos kariuomenès karininkai 1918-1953“45.

Gudų pasitelkimą atstovaujant Lietuvos piliečių interesams Turkijoje, Jugoslavijoje ir ypač Bulgarijoje, Komiteto Konstantinopolyje gudų globą ir bendradarbiavimo su jais kontekstą suvokti padeda Edmundo Gimžausko monografija „Baltarusių veiksnys formuojantis Lietuvos valstybei 1915-1923 m." ${ }^{46}$. Joje aptartas Lietuvos ir Baltarusijos (tiksliau - Gudu Liaudies Respublikos vyriausybès, vad. V. Lastauskio) 1920 m. lapkričio 11 d. pasirašytas susitarimas, kurio 4 paragrafas (juo abi vyriausybès įsipareigojo palaikyti viena kitą užsienyje) dèl atstovavimo Balkanų šalyse ir Turkijoje buvo igyvendinamas praktiškai.

Lyginant latvių pabėgèlių grąžinimo iš Turkijos ir Balkanų šalių ypatu-

\footnotetext{
42 Aničas J. Petras Vileišis 1851-1926. Vilnius: Alma littera, 2001, p. 435, 438.

43 Užsienio reikalų ministerijos žinynas. Kaunas, 1933, p. 232.

44 Kasparavičius A. Tarp politikos ir diplomatijos: Šventasis Sostas ir Lietuvos Respublika. Vilnius: LII leidykla, 2008 [762 p.], p. 76-77.

45 Lietuvos kariuomenes karininkai, 1918-1953. T. 5. Vilnius: Lietuvos nacionalinis muziejus, 2005, p. 114. (Už nuorodą dèkoju kolegei dr. Aušrai Jurevičiūtei.)

46 Gimžauskas E. Baltarusių veiksnys formuojantis Lietuvos valstybei 1915-1923 m. Vilnius: LLI leidykla, 2003, p. 126-137.
} 
mus svarbūs Latvijos istorikų darbai, Ainaro Lerhio (Ainārs Lerhis) darbas apie Latvijos Respublikos atstovybes užsienyje. Iš A. Lerhio atlikto tyrimo aiškejja keletas labai svarbių dalykų. Pirma, Latvijos užsienio reikalų ministerija vykdè latvių pabėgèlių grąžinimą iš Vidurio Europos, Balkanų šalių, Turkijos panašiu laiku kaip ir Lietuva - 1920 m. liepą-1921 m. balandị. Antra, ji tai darè, siųsdama ị misiją diplomatinị atstovą ir vyriausybès delegatą Aleksandrą Kacensą (Aleksandrs Kacens) ir sekretorių bei konsulinį agentą Konradą Kacensą (Konrāds Kacens). A. Kacensas turëjo Latvijos vyriausybès igaliojimą grąžinti (repatrijuoti ir reevakuoti) latviụ pabègèlius iš Austrijos, Azerbaidžano, Bulgarijos, Čekoslovakijos, Jugoslavijos, Gruzijos, Graikijos, Rumunijos ir Turkijos. Trečia, latvių pabėgèliai grị̌zo kitu nei lietuviai maršrutu: Tiflisas-Konstantinopolis-SofijaBelgradas-Viena-Praha-Varšuva-Klaipèda-Liepoja ${ }^{47}$.

Iš Ėriko Jekabsono (Ēriks Jēkabsons) ir Valterio Ščerbinskio (Valters Ščerbinskis) biografiniame žodyne esančios Aleksandro Kacenso biografijos $^{48}$ aiškejja, kad A. Kacensas, Latvijos vyriausybès iggaliotinis Rumunijoje, Turkijoje ir Ukrainoje, turejo karinị išsilavinimą (buvo baigęs Kazanès karo mokyklą) ir 1919 m. pabaigoje gavo kapitono laipsnị. Kapitono laipsnis jam buvo suteiktas adm. A. Kolčako už nuopelnus Sibiro vyriausybei. Jis, kaip ir kpt. B. Blaveščiūnas, baigęs tarnybą Rusijos kariuomenèje, perèjo dirbti ị diplomatinę tarnybą. I misiją $1921 \mathrm{~m}$. pasiųstas vyr. ltn. Juozas Macevičius, kaip ir A. Kacensas, buvo studijavęs Novorosijsko universitete (Odesoje). Todèl J. Macevičiaus kandidatūra misijai į Balkanų šalis ir Turkiją, straipsnio autorès manymu, pasirinkta neatsitiktinai.

Apžvelgę lietuvių ir latvių istoriografiją, tiesiogiai ar netiesiogiai susijusią su Lietuvos ir (ar) Latvijos piliečių karo pabėgèlių, tremtinių ir belaisvių grąžinimu ị tèvynę iš Turkijos, Jugoslavijos ir Bulgarijos, jų interesų atstovavimu išvardintose šalyse, galime teigti, kad šiuo aktualiu Lietuvos istorijos klausimu iki šiol dar nèra mokslo publikacijos - vien fragmentai kitų XX a. Lietuvos istorijos problemų kontekste.

47 Lerhe A. Latvijas Respublikas ārlietu dienests 1918-1941. Rīga, 2005, lpp. 143-144.

48 Jēkabsons Ē., Ščerbinskis V. Latvijas ārlietu dienesta darbinieki 1918-1991. Biogrāfiska vārdnīca. Rīga: Zinātne, 2003, p. 147-149. 


\section{2. Šaltiniai}

Lietuvos konsulinių institucijų Turkijoje, Jugoslavijoje ir jose dirbusių igaliotinių veiklos analizei atlikti daugiausia informacijos yra nepublikuotuose šaltiniuose, saugomuose Lietuvos centriniame valstybės archyve (toliau - LCVA). Svarbiausi tyrimui dokumentai yra Lietuvos Respublikos užsienio reikalų ministerijos 383 fonde, 7 apraše. Jame esančiose bylose saugoma Lietuvos užsienio reikalų ministerijos susirašinèjimo su Lietuvos vyriausybės igaliotiniu Turkijoje kpt. B. Blaveščiūnu, Lietuvos atstovybėmis Vokietijoje, Didžiojoje Britanijoje, Latvijoje, Prancūzijoje, Šveicarijoje, Italijoje ir prie Šventojo Sosto dèl pabègèliu grąžinimo iš Turkijos ir Balkanų šalių korespondencija. Iš jos aiškejja komitetų (vèliau - konsulinių atstovybių) ¡̇kūrimo Konstantinopolyje ir Belgrade aplinkybės, Komiteto Sofijoje, juose dirbusių karininkų veikla grąžinant karo pabėgèlius ị Lietuvą ir jos vertinimas, finansinè situacija, uždarymo aplinkybès. Svarbi ir jose esanti informacija apie vyr. ltn. Juozo Macevičiaus (1921 m. gegužès-rugsèjo mèn.) ir Vaclovo Sidzikausko (1922 m. kovo mèn.) misijas Turkijoje, Jugoslavijoje ir Bulgarijoje.

Archyvinès informacijos spragas užpildyti padeda to meto Lietuvos spauda ir atsiminimai. Apie Komitetą Konstantinopolyje ir kelią, kuriuo buvo grį̌zama i Lietuvą iš Turkijos, rašoma dienraštyje „Lietuva“. Leidinyje pateikta informacija padejo patikslinti ir papildyti archyvinius duomenis apie kpt. B. Blaveščiūnui suteiktų igaliojimų laiką ir jo veiklą Konstantinopolyje rūpinantis lietuviais pabègèliais ${ }^{49}$. Ypač vertingos medžiagos tyrimui suteikia Lietuvos diplomato Vaclovo Sidzikausko atsiminimai. Tuo metu jis buvo Lietuvos Respublikos atstovas Šveicarijoje ir $1921 \mathrm{~m}$. pabaigoje (atsiminimuose teigiama, kad $1922 \mathrm{~m}$. pavasari S. G.) ministerijos jam buvo patiketa misija uždaryti veikiančias konsulines Lietuvos atstovybes Turkijoje ir Jugoslavijoje ir nutraukti Lietuvių komiteto Sofijoje veiklą. Atsiminimuose kone ištisai pateikiamas jo $1921 \mathrm{~m}$. balandžio mẻnesị Užsienio reikalų ministerijai rašytas pranešimas-ataskaita apie misijos įvykdymą ${ }^{50}$. Tačiau V. Sidzikausko atsimini-

49 Iš Kaukazo į Lietuvą. Lietuva, 192102 26, Nr. 45, p. 2; Lietuvių vargai Konstantinopoly. Lietuva, 192102 12, Nr. 34, p. 3.

50 Sidzikauskas V. Lietuvos diplomatijos paraštėje. Vilnius: Vaga, 1994, p. 33-47. 
mų tekste, palyginti su pranešimu ministerijai, akivaizdžiai stinga keleto dalykų. Pirmiausia juose nerasime jokios konkrečios informacijos apie konsulinių atstovybių finansinę būklę. Antra, apie J. Macevičiaus misiją tik užsiminta, bet neįvardyti jo konkrečiai atlikti veiksmai (tarytum jos ir nebuvo). Trečia, neįvardyta konkreti kpt. B. Blaveščiūno veikla padedant Lietuvos piliečiams ir kpt. L. Lippingo pastangos ginti Lietuvos interesus Jugoslavijoje. Ir ketvirta, ypač iškelti jo paties, t. y. V. Sidzikausko, nuopelnai „sutvarkant reikalą"51.

Ivertinę šaltinius ir istoriografiją galime ịvardyti tris iki šiol neišspręstas problemas: pirmoji - Lietuvos atstovavimui Turkijoje ir Balkanų šalyse 1920-1922 m. lietuvių istoriografijoje dèmesio praktiškai neskirta, antroji - publikuotuose šaltiniuose akcentuojamas V. Sidzikausko vaidmuo uždarant konsulines atstovybes, bet neatskleidžiamas grįžimo procesą iš Turkijos ir Balkanų šalių organizavusių ir jị koordinavusių karininkų indèlis, trečia - nepublikuotuose šaltiniuose yra labai skirtingų komitetuose ir konsulinėse atstovybėse dirbusių asmenų vertinimų, todèl, neatlikus išsamaus tyrimo, sunku šiuos vertinimus patvirtinti arba paneigti.

\section{LIETUVOS RESPUBLIKOS PILIEČIŲ KOMITETAS KONSTANTINOPOLYJE $1920 \mathrm{M}$. LAPKRIČIO 1 D.-1921 M. VASARIO 9 D.: ISTEIGIMAS, NARIAI, VEIKLA}

\subsection{Lietuvos Respublikos piliečių komiteto Konstantinopolyje ịsteigimo aplinkybès}

Lietuvos Respublikos piliečių komiteto Konstantinopolyje (toliau - Komitetas Konstantinopolyje) ìkūrimo aplinkybès jo pirmininko kpt. B. Blaveščiūno ir Užsienio reikalų ministerijos aiškinamos skirtingai, tačiau esmè ta pati - Turkijoje atsiradusiems apie 200 Lietuvos piliečių,

51 Sidzikauskas V. Lietuvos diplomatijos paraštėje. Vilnius: Vaga, 1994, p. 35. 
pirma, reikejjo dokumentų, kuriuos pripažintų Antantės aukštieji komisarai Konstantinopolyje ir kitų Europos šalių, per kurias lietuviai galèjo grịžti ị Lietuvą, vyriausybès. Antra, jie neturejjo kur apsistoti, kol atsiras galimybė išvykti į tėvynę, ir lèšų, kad galètų pragyventi. B. Blaveščiūnas pirmame pranešime URM aiškino, kad Konstantinopolyje esantys lietuviai „turi liudijimus apie jų lietuvišką kilmę, bet neturi reikalingų dokumentų (pasų), kad galètų tęsti kelionę “52. Tai buvo tiesa, nes dar iki B. Blaveščiūno atvykimo Konstantinopolyje jau buvo apie 50 pabėgèlių su Krymo lietuvių komiteto pasais, kurių užsienio valstybès nevizavo, todèl jie negalèjo grị̌żi ị Lietuvą ${ }^{53}$. Buvo akivaizdu, kad Konstantinopolyje reikia organo, kuris gintų lietuvių interesus. Todèl buvo sušauktas „Lietuvos piliečių susirinkimas" ${ }^{5_{4}}$ situacijai aptarti ir ịkurtas Komitetas Konstantinopolyje ${ }^{55}$.

Komiteto ar kito lietuviams (Lietuvos piliečiams) atstovaujančio organo reikejjo dar ir dèl kitų priežasčių. Dauguma Konstantinopolyje esančių lietuvių buvo karininkai, tarnavę Rusijos kariuomenejje. Dalis jų (vieni - savanoriškai, kiti - prievarta) tarnavo gen. ltn. A. Denikino ir gen. ltn. P. Vrangelio armijoje ir i Turkiją pasitrauke kartu su $j^{56}$. Tiek kariškiai, tiek kai kurie civiliai pabègèliai negalejjo grịžti ị Lietu-

5219201120 B. Blaveščiūno raportas URM apie Lietuvos piliečių komitetą Konstantinopolyje. LCVA, f. 383, ap. 7, b. 214, 1. 66-67.

5319211104 užsienio reikalų ministro laiškas Lietuvos atstovui Šveicarijoje V. Sidzikauskui. LCVA, f. 383, ap. 7, b. 257, 1. 38.

54 Užsienio reikalų ministras buvo skeptiškos nuomonès apie Konstantinopolyje sušauktą „lietuvių susirinkimą“, kuris išrinko Komitetą Konstantinopolyje. Jis V. Sidzikauskui rašè: „Tame susirinkime iš tikrų lietuvių vargu bau kas buvo dalyvavęs. Tatai matyti iš išrinkto komiteto sąstato. “Žr.: 19211104 užsienio reikalų ministro laiškas Lietuvos atstovui Šveicarijoje V. Sidzikauskui. LCVA, f. 383, ap. 7, b. 257, 1. 38.

5519201120 B. Blaveščiūno raportas URM apie Lietuvos piliečių komitetą Konstantinopolyje. LCVA, f. 383, ap. 7, b. 214, 1. 66-67.

56 Gen. ltn. A. Denikino ir gen. ltn. P. Vrangelio armijos likučiai, spaudžiami bolševikų, traukèsi iš Krymo. Dalis jų laivais pasiekė Konstantinopolį. Gen. ltn. P. Vrangelio daliniuose buvo nemažai lietuvių karininkų ir eilinių karių. Lietuvos vyriausybė stengèsi išlaisvinti lietuvius nuo tarnybos gen. ltn. P. Vrangelio kariuomenèje. Tuo nuo $1920 \mathrm{~m}$. rugsèjo mèn. rūpinosi Steigiamojo Seimo kanceliarijos direktorius, ypatingasis igaliotinis Ukrainoje Andrius Lisauskas (jis buvo ir Lietuvos taikos derybų su Ukraina delegacijos narys - S. G.) ir Rapolas Juodelè. Jie Lietuvos URM buvo išsiųsti ị specialią misiją - turèjo išduoti pa- 
vą, nes su „Rusijos pasais“ užsienio valstybės jų neįsileido. Taigi reikëjo kitos valstybès dokumentų ${ }^{57}$.

Komitetų Lietuvos piliečių interesams ginti (Lietuvių komitetų, Tautos tarybų ir pan.) steigimo praktika 1917-1920 m. egzistavo tiek irstančioje Rusijos imperijoje (Rusijoje, Ukrainoje, Gruzijoje, Azerbaidžane), tiek kitose užsienio šalyse (Turkijoje, Jugoslavijoje). Komitetai, susisiekę su Lietuvos Valstybès Taryba, o vèliau - su Laikinąja Lietuvos vyriausybe, gaudavo oficialų igaliojimą atstovauti Lietuvos piliečių interesams priimančiojoje šalyje ir tapdavo Lietuvos Valstybès Tarybos arba Laikinosios Lietuvos vyriausybès igaliotiniais ${ }^{58}$. Analogiška praktika buvo ir Latvijoje ${ }^{59}$. Paskirtieji igaliotiniai turèjo konsulinius igaliojimus ${ }^{60}$.

Apie Komiteto Konstantinopolyje ịkūrimą pranešimą Lietuvos užsienio reikalų ministerijai kpt. B. Blaveščiūnas išsiunte $1920 \mathrm{~m}$. lapkričio 20 d. Kaune jis buvo gautas 1920 m. gruodžio 13 d. ${ }^{61}$ Komiteto Konstantinopolyje būstinès adresas - Minareto g. 5, Pera, Osmali-Medid pusé,

sus lietuviams Pietų Rusijoje, Ukrainoje ir Kryme ir pasirūpinti, kad ị gen. ltn. Vrangelio kariuomenę mobilizuoti lietuviai būtų paleisti ir grąžinti ị Lietuvą. Dalis Pietų Rusijoje ir Kryme buvusių lietuvių grị̌zo per Rumuniją ir Čekoslovakiją. A. Lisauskas susitarè dèl jų kelionès per Rumunijos ir Čekoslovakijos teritoriją. I Lietuvą grị̌zo apie 300 lietuvių tremtinių. A. Lisauskas misiją baigè $1921 \mathrm{~m}$. balandžio 3 d. ir iš Odesos per Rumuniją grị̌zo ì Lietuvą. Žr.: Tremtinių reikalai. Laivè, 192009 16, Nr. 189, p. 1; Mūsų tremtiniai grịžta iš Pietų Rusijos. Laisvè, 192101 09, Nr. 6, p. 1; Kaunas: Elta, 192104 19. Laisvè, 192104 21, Nr. 86, p. 1; 1922 m. balandžio (pranešime data nenurodyta) V. Sidzikausko pranešimas URM apie misiją Turkijoje, Jugoslavijoje ir Bulgarijoje. LCVA, f. 383, ap. 7, b. 257, 1. 7.

5719211104 užsienio reikalų ministro laiškas Lietuvos atstovui Šveicarijoje V. Sidzikauskui. LCVA, f. 383, ap. 7, b. 257, 1. 38.

58 Grigaravičiūtè S. Lietuvos igaliotiniai, jų statusas ir funkcijos 1918-1922 metais. Pranešimas skaitytas nacionalinejje mokslinèje konferencijoje „Lietuvos diplomatija ir diplomatai XV-XXI a. (I)“ (LEU, Vilnius) 201512 04. Grigaravičiūtè S. Diplomacy of the Council of Lithuania (September 1917-May 1920). Vesture: avoti un cilveki. XXV starptautisko zinatnisko lasijumu materiali. Vesture XIX. Daugavpils Universitates Akademiskais apgads „Saule“, 2016, p. 90-104; Grigaravičiūtė S. Lithuanian-Latvian Consular Cooperation in Vladivostok, 1921-1922. Pranešimas skaitytas tarptautineje mokslinèje konferencijoje „The $17^{\text {th }}$ International Scientific Conference. Society and Culture: Science Through the Ages" (Liepaja University, Liepaja) 20160522.

59 Lerhe A. Latvijas Respublikas ārlietu dienests 1918-1941. Rīga, 2005, lpp. 133-139.

60 Mūsų tremtinių ir jų turtų grąžinimas iš Sovietų Rusų (pašnekesys su S. Šimkum). Lietuva, 192103 12, Nr. 56, p. 1.

6119201120 B. Blaveščiūno pranešimas Lietuvos URM. LCVA, f. 383, ap. 7, b. 214, 1. 65. 
Konstantinopolis (pranc. k. Rue Minaret Pera Nr. 5, Côté Osmali-Medid, Constantinopole $)^{62}$.

\subsection{Komiteto Konstantinopolyje nariai ir jų charakteristika}

1920 m. lapkričio 1 d. susikūrusị komitetą sudarè penki nariai, trys iš jų - išèję i atsargą Rusijos kariuomenès karininkai, kilę iš Kauno gubernijos - kapitonas Bronius Blaveščiūnas, leitenantai Andrejus Milleris ir Anatolis Pokramovičius, - ir du iš Suvalkų ir Gardino gubernijų kilę asmenys - Salomonas Geselsonas ir Jakobas Abramovičius (žr. 1a ir $1 \mathrm{~b}$ lenteles) ${ }^{63} .1921 \mathrm{~m}$. lapkričio $4 \mathrm{~d}$. užsienio reikalų ministro laiške V. Sidzikauskui abejojama, ar susirinkime, kuris išrinko Komitetą Konstantinopolyje, „iš tikrų lietuvių vargu bau kas buvo dalyvavęs“. Nesant tikslesnių duomenų apie susirinkimo dalyvius, nei pavirtinti, nei paneigti šios ministro abejonès negalime. Kiek vèliau Komiteto Konstantinopolyje sudètis keitèsi. A. Milleris dèl neteisètai išduodamų Lietuvos pasų iš Komiteto Konstantinopolyje buvo pašalintas. I Komitetą buvo paskirti nauji nariai - plk. A. Benjaševičius, kpt. Leopoldas Lippingas ir kpt. Šiaučiūnas ${ }^{64}$. Komiteto Konstantinopolyje biuras įsikūre europinejje Konstantinopolio dalyje - Pera (Péra), kurioje telkèsi pabėgèliai (kariai ir civiliai) iš Rusijos ${ }^{65}$.

6219210209 viceministro P. Klimo telegrama ị Konstantinopolị B. Blaveščiūnui. LCVA, f. 383 , ap. 7, b. 214, 1. 60. Tas pat prancūzų kalba. LCVA, f. 383, ap. 7, b. 214, 1. 53.

6319201120 B. Blaveščiūno raportas URM apie Lietuvos piliečių komitetą Konstantinopolyje. LCVA, f. 383, ap. 7, b. 214, 1. 66-67.

6419210303 URM PDD direktoriaus B. K. Balučio pro memoria (apie Lietuvių komitetą ir lietuvių tremtinius Konstantinopolyje). LCVA, f. 383, ap. 7, b. 214, 1. 39.

65 Iš Kaukazo ị Lietuvą. Lietuva, 192102 26, Nr. 45, p. 2. 
1a lentelè. Komiteto Konstantinopolyje valdybos narių sąrašas su Lietuvos URM 19201127 apie juos pateikta informacija

\begin{tabular}{|c|c|c|c|c|}
\hline $\begin{array}{l}\text { Komiteto nario vardas } \\
\text { ir pavardè (lietuvių ir } \\
\text { prancūzų kalbomis) }\end{array}$ & $\begin{array}{l}\text { Statusas } \\
\text { komitete }\end{array}$ & $\begin{array}{l}\text { Turimas } \\
\text { kario } \\
\text { laipsnis }\end{array}$ & $\begin{array}{c}\text { Gimimo } \\
\text { (kilmės) } \\
\text { vieta }\end{array}$ & Išsilavinimas \\
\hline $\begin{array}{c}\text { Bronius Blaveščiūnas } \\
\text { (Bronislav } \\
\text { Blaviestchounasse) }\end{array}$ & $\begin{array}{l}\text { pirmi- } \\
\text { ninkas }\end{array}$ & kapitonas & $\begin{array}{l}\text { Panevėžys, } \\
\text { Kauno } \\
\text { gubernija }\end{array}$ & $\begin{array}{c}\text { Baigęs Imperatoriaus } \\
\text { Aleksandro kadetų } \\
\text { mokyklą Sankt } \\
\text { Peterburge, buvo } \\
\text { Politechnikos instituto } \\
\text { ekonomikos studentas. } \\
\text { Baigęs Kaukazo } \\
\text { aviacijos mokyklos } \\
\text { teorini kursą ir pilotų } \\
\text { aukštojo pilotavimo } \\
\text { kursus Sevastopolyje }\end{array}$ \\
\hline $\begin{array}{l}\text { Andrejus Milleris } \\
\text { (Andrei Miller) }\end{array}$ & $\begin{array}{l}\text { sekre- } \\
\text { torius }\end{array}$ & $\begin{array}{c}\text { jūrų } \\
\text { laivyno } \\
\text { leitenantas }\end{array}$ & $\begin{array}{l}\text { Panevėžys, } \\
\text { Kauno } \\
\text { gubernija }\end{array}$ & $\begin{array}{c}\text { Baigęs jūreivių kadetų } \\
\text { mokyklą Sankt } \\
\text { Peterburge }\end{array}$ \\
\hline $\begin{array}{c}\text { Anatolijus } \\
\text { Pokramovičius } \\
\text { (Anatoli Pokramovitche) }\end{array}$ & narys & $\begin{array}{c}\text { jūrų } \\
\text { laivyno } \\
\text { leitenantas }\end{array}$ & $\begin{array}{l}\text { Kauno } \\
\text { gubernija }\end{array}$ & $\begin{array}{l}\text { Baigęs jūreivystės } \\
\text { mokyklos Sankt } \\
\text { Peterburge kursą }\end{array}$ \\
\hline $\begin{array}{l}\text { Salomonas Geselsonas } \\
\text { (Salomon Guesselson) }\end{array}$ & narys & - & $\begin{array}{l}\text { Vilkaviškio } \\
\text { apskritis, } \\
\text { Suvalkų } \\
\text { gubernija }\end{array}$ & $\begin{array}{c}\text { Baigęs Kauno } \\
\text { gimnaziją ir Esene } \\
\text { esančio Fridbergo } \\
\text { politechnikos instituto } \\
\text { kursą }\end{array}$ \\
\hline $\begin{array}{l}\text { Jokūbas Abramovičius } \\
\text { (Jakob Abramovitch) }\end{array}$ & $\begin{array}{l}\text { iždi- } \\
\text { ninkas }\end{array}$ & - & $\begin{array}{l}\text { Slonimas, } \\
\text { Gardino } \\
\text { gubernija }\end{array}$ & $\begin{array}{l}\text { Baigęs gimnaziją } \\
\text { Bialystoke }\end{array}$ \\
\hline
\end{tabular}

Sudaryta autorès remiantis: 19201120 B. Blaveščiūno raportas URM apie Lietuvos piliečių komitetą Konstantinopolyje. LCVA, f. 383, ap. 7, b. 214, 1. 66-67.

1 b lentelè. $1921 \mathrm{~m}$. vasario mèn. Komiteto Konstantinopolyje valdybos narių sąraše minimi nariai

\begin{tabular}{|c|c|c|c|c|}
\hline $\begin{array}{c}\text { Komiteto nario vardas } \\
\text { ir pavardė (lietuvių ir } \\
\text { prancūzu kalbomis) }\end{array}$ & $\begin{array}{c}\text { Statusas } \\
\text { komitete }\end{array}$ & $\begin{array}{c}\text { Turimas } \\
\text { kario laipsnis }\end{array}$ & $\begin{array}{c}\text { Gimimo (kilmės) } \\
\text { vieta }\end{array}$ & $\begin{array}{c}\text { Išsila- } \\
\text { vinimas }\end{array}$ \\
\hline Algirdas Benjaševičius & narys & pulkininkas & Vilniaus gubernija & \\
\hline $\begin{array}{c}\text { Šiaučiūnas } \\
\text { (vardas nežinomas) }\end{array}$ & narys & kapitonas & & \\
\hline Leopoldas Lippingas & narys & kapitonas & & \\
\hline
\end{tabular}

Sudaryta autorès remiantis: 19210303 URM PDD direktoriaus B. K. Balučio pro memoria (apie Lietuvių komitetą ir lietuvių tremtinius Konstantinopolyje). LCVA, f. 383, ap. 7, b. 214, 1. 39. 
Komiteto pirmininku tapęs 27 metų kpt. Bronius Blaveščiūnas iš pradžių užsienio reikalų viceministro, Politikos ir Bendrųjų reikalų departamentų direktorių buvo vertinamas skeptiškai, tačiau jo pastangos ir darbai grąžinant Lietuvos piliečius iš Turkijos, konsulinių igaliotinių Jugoslavijoje ir Bulgarijoje veiklos koordinavimas (1921-1922 m.) priverte juos pakeisti nuomonę. Prie skeptiškos nuomonès apie kpt. B. Blaveščiūną formavimo prisidejo ir plk. Banevičiaus (vardas autorei nežinomas), grị̌zusio su pirmąja lietuvių banga iš Konstantinopolio, B. Balučiui išsakyta nuomone apie komiteto (bet ne B. Blaveščiūno - S. G.) veiklą. Raštuose ministerijai ir Lietuvos atstovams Europoje jis buvo pristatomas kaip „pasiturinčio valdininko“ sūnus, kuriam lietuvių kalbos mokyti „tèvas pasamdè lietuvių mokytoją studentą Žilinską “66. Ir vyr. Itn. J. Macevičius, ir V. Sidzikauskas, revizavę B. Blaveščiūno veiklą Konstantinopolyje 1921-1922 m. (apie tai žr. toliau tekste), vertino teigiamai. Teigiamai apie Komiteto Konstantinopolyje pirmininką atsiliepė ir buvęs Prancūzijos aukštojo komisaro Konstantinopolyje Pasų tarnybos viršininkas karininkas Leleu ${ }^{67}$.

Labiausiai šešèli Komiteto Konstantinopolyje veiklai metė sekretoriumi išrinktas ltn. A. Milleris, komiteto nariu tapęs greičiausiai, kad pasipelnytų, ir iždininkas J. Abramovičius. Abu išvyko ị Bulgariją. Pirmasis 1921 m. pradžioje, antrasis - 1921 m. viduryje. Abiejų 1921 m. kovo mėn. gauti Lietuvos pasai buvo anuliuoti ${ }^{68}$. Kiek vèliau ị Komiteto Konstantinopolyje valdybos narių sąrašą dar buvo įtraukti plk. A. Benjaševičius, kpt. Leopoldas Lippingas ir kpt. Šiaučiūnas ${ }^{69}$.

Komiteto Konstantinopolyje pirmininkas B. Blaveščiūnas pirmame pranešime URM prašè: 1) Lietuvos Vyriausybès pripažinti Lietuvos Respublikos piliečių komitetą Konstantinopolyje kaip kompetentingą organizaciją, išduodančią liudijimus lietuviams, kurie neturi pasų, bet turi lietuvišką kilmę ịrodančius dokumentus; 2) leisti veikti Lietuvos Respublikos vyriausybės vardu siekiant apginti Lietuvos piliečių interesus;

\footnotetext{
661922 m. balandžio (pranešime data nenurodyta) V. Sidzikausko pranešimas URM apie misiją Turkijoje, Jugoslavijoje ir Bulgarijoje. LCVA, f. 383, ap. 7, b. 257, 1. 11 a.

67 Ten pat, 1. 9.

6819220328 V. Sidzikausko nota Bulgarijos URM. LCVA, f. 383, ap. 7, b. 257, 1. 18.

6919210303 URM PDD direktoriaus B. K. Balučio pro memoria (apie Lietuvių komitetą ir lietuvių tremtinius Konstantinopolyje). LCVA, f. 383, ap. 7, b. 214, 1. 39.
} 
3) atsiųsti instrukcijų ${ }^{70}$.

1921 m. vasario mèn. Komitetas Konstantinopolyje, paskyrus kpt. B. Blaveščiūną Lietuvos vyriausybès igaliotiniu Turkijoje, buvo reorganizuotas i Lietuvos Respublikos konsulinę atstovybę Konstantinopolyje (Turkijoje). J. Abramovičius tapo igaliotinio sekretoriumi ir „iždininku“"71, o Aleksandras Lazarevas - vertejju ${ }^{72}$.

\subsection{Komiteto Konstantinopolyje funkcijos}

Penkios pagrindinès Komiteto Konstantinopolyje funkcijos buvo išdèstytos $1920 \mathrm{~m}$. lapkričio $20 \mathrm{~d}$. pranešime Lietuvos užsienio reikalų ministerijai prancūzų kalba. Pranešimą pasirašè visi penki Komiteto Konstantinopolyje nariai. Pranešimas, greičiausiai rašytas sekretoriaus ltn. A. Počamovičiaus (Poczamowitch), nes kpt. B. Blaveščiūnas, ministerijos duomenimis, prancūzų kalbos nemokejo. Pirmoji pranešime nurodyta funkcija - užmegzti ryšius su Lietuvos Respublikos vyriausybe ir informuoti apie Lietuvos piliečių padètị Turkijoje. Antroji - užmegzti ryšius su vietos valdžia ir išsiaiškinti lietuvių išvykimo iš Konstantinopolio galimybes (jūra ar sausuma, ir kelionès kainą). Tai buvo svarbus uždavinys, nes Konstantinopoli tuomet kontroliavo Antantès valstybès, tad Komitetui Konstantinopolyje reikejo gauti Antantės aukštųjų komisarų Konstantinopolyje pripažinimą ir visą i̇manomą paramą. Trečioji funkcija - pasirūpinti lietuvių pabėgèlių gyvenamąa vieta ir maitinimu, kad jie galètų „gyventi Konstantinopolio barakuose karo pabėgèliams, kaip ir pabėgèliai iš Estijos ir Latvijos“. Dauguma pabėgèlių i Konstantinopoli atvyko be pinigų ir be dokumentų, todèl neturejo nei kur, nei iš ko gyventi, o neturèdami reikiamų dokumentų, negalejjo išvykti. Tai buvo trečiosios, nurodytos Komiteto Konstantinopolyje, funkcijos dalis - prašyti aukštojo Prancūzijos komisaro Konstantinopolyje leidimo pabègèliams lietuviams išvykti ị tėvynę ${ }^{73}$. Ket-

\footnotetext{
7019201120 B. Blaveščiūno raportas URM apie Lietuvos piliečių komitetą Konstantinopolyje. LCVA, f. 383, ap. 7, b. 214, 1. 69-69a.

$711922 \mathrm{~m}$. balandžio (pranešime data nenurodyta) V. Sidzikausko pranešimas URM apie misiją Turkijoje, Jugoslavijoje ir Bulgarijoje. LCVA, f. 383, ap. 7, b. 257, 1. 7.

7219211104 užsienio reikalų ministro laiškas Lietuvos atstovui Šveicarijoje V. Sidzikauskui. LCVA, f. 383, ap. 7, b. 257, 1. 39.

7319201120 B. Blaveščiūno raportas URM apie Lietuvos piliečių komitetą Konstantino-
} 
virtoji funkcija buvo ta, dèl kurios iš esmès ir buvo įsteigtas Komitetas Konstantinopolyje, - išduoti pažymėjimus (certificat), kad galètų išvykti, tiems, kurie neturi pasų, bet turi dokumentus, galinčius ịrodyti jų lietuvišką kilmę. Na ir penktoji funkcija - ginti lietuvių interesus ${ }^{74}$.

\subsection{Komiteto Konstantinopolyje pirmininko kpt. Broniaus Blaveščiūno veikla (1920 m. lapkričio-1921 m. sausio mẻn.)}

\subsubsection{Pabėgèlių apgyvendinimo, maitinimo organizavimas, pasų ir vizų išdavimas}

Tik susikūrus Komitetui, pirmiausia imta rūpintis finansine parama. Kpt. B. Blaveščiūnas kaip Komiteto Konstantinopolyje pirmininkas lankèsi pas sultoną, kelis princus, didiji vizirị, Konstantinopolyje reziduojantị Popiežiaus nuncijų mgr. Angelo Maria Dolci, prašęs paremti lietuvių pabėgèlius ir gavęs tam tikslui pinigų. Konkreti suma šaltiniuose neịvardyta $^{75}$. B. Blaveščiūno pastangomis buvo įsteigtas bendrabutis lietuviams pabėgèliams, $\mathfrak{i}$ kurị iš įvairių rusų pabėgèlių stovyklų buvo perkelti lietuviai, iki gaus leidimą grižzi i Lietuvą ${ }^{76}$. Konstantinopolyje pabègèliams padejjo Amerikos Raudonasis Kryžius ${ }^{77}$. Jis buvo ịsteigęs valgyklų, duodavo pabėgèliams drabužių ir 40 Turkijos lirų kelionès išlaidoms padeng$\mathrm{ti}^{78}$. Pirmiausia buvo stengiamasi grąžinti ị Lietuvą asmenis, prieš Pirmąji pasaulinị karą gyvenusius Kauno gubernijoje. Tačiau rūpintasi ir tais, kurie buvo kilę iš Vilniaus, Gardino, Naugarduko, Ilukštès ir Daugpilio (oficialiai tokiems asmenis ị Lietuvą grị̌zi nebuvo leidžiama - S. G. (79. $^{79}$

Viena pagrindinių Komiteto Konstantinopolyje veiklų buvo pasų ir

polyje. LCVA, f. 383 , ap. 7, b. 214, 1. 67-67a.

74 Ten pat.

751922 m. balandžio (pranešime data nenurodyta) V. Sidzikausko pranešimas URM apie misiją Turkijoje, Jugoslavijoje ir Bulgarijoje. LCVA, f. 383, ap. 7, b. 257, 1. 9.

76 Ten pat, 1. 11a.

7719201120 B. Blaveščiūno raportas URM apie Lietuvos piliečių komitetą Konstantinopolyje. LCVA, f. 383, ap 7, b. 214, 1. 68-68a.

78 Eltos pranešimas. LCVA, f. 383, ap. 7, b. 214, 1. 56-57.

7919211104 užsienio reikalų ministro laiškas Lietuvos atstovui Šveicarijoje V. Sidzikauskui. LCVA, f. 383, ap. 7, b. 257, 1. 39-39a; 41a. 
vizų išdavimas Lietuvos piliečiams. Nuo 1920 m. lapkričio 1 iki $1921 \mathrm{~m}$. vasario 28 d. buvo išduoti 668 ịregistruoti pasai (įrašyti pasų registracijos

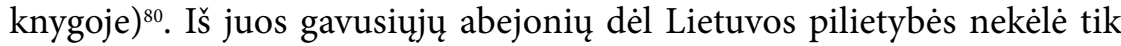
125 asmenys, likusieji Lietuvos Respublikos pasus gavo pateikę netiesioginius įrodymus arba kitų asmenų liudijimus) ${ }^{81}$.

Komitetas Konstantinopolyje nuomojo biuro patalpas ir samdè raštinès tarnautojus, mokejjo jiems algą. Pagrindines pajamas sudarè už pasus ir vizas gauti pinigai, tačiau jų neužteko. Komitetas už liudijimo išdavimą èmė 4 Turkijos liras (ltgs), už vizą i Lietuvą - 1 ltgs. B. Blaveščiūnas pirmajame pranešime URM skundèsi, kad nèra kuo maitinti pabėgèlių. Jụ maisto dienos norma kainavo „65 piastus“. Kad galima būtų pragyventi Konstantinopolyje mėnesį, reikèjo 150 Turkijos lirų ${ }^{82}$. Kpt. B. Blaveščiūnas mokesčiams už nuomą ir tarnautojų algoms skolinosi pinigų iš privačių asmenų. Iš pradžių kpt. B. Blaveščiūnui talkino jo sekretorius ltn. A. Milleris, iždininkas J. Abramovičius ir vertejjas Aleksandras Lazarevas ${ }^{83}$.

Komitetas Konstantinopolyje siekè palaikyti ryši su Lietuvių komitetu Kryme. Konstantinopolyje buvo įsikūrusi ir kurị laiką veikè Stojanavskio ${ }^{84}$ vadovaujama „Lietuvių-estų prekybos ir transporto draugija“. Kpt. B. Blaveščiūnas buvo išdavęs jai igaliojimą „reevakuoti ir repatrijuoti palikusius Rusijoje Lietuvos piliečius“" ${ }^{\text {(85. }}$. Apie tai, kad „Lietuvių-estų prekybos ir transporto draugija“ tarpininkaus „tarp atbėgusių Turkijon ir pasilikusių Rusijoje Lietuvos piliečių giminių ir pažįstamų ir kad jis

801922 m. balandžio (pranešime data nenurodyta) V. Sidzikausko pranešimas URM apie misiją Turkijoje, Jugoslavijoje ir Bulgarijoje. LCVA, f. 383, ap. 7, b. 257, 1. 10.

81 Ten pat.

8219201120 B. Blaveščiūno raportas URM apie Lietuvos piliečių komitetą Konstantinopolyje. LCVA, f. 383, ap. 7, b. 214, 1. 69.

8319211104 užsienio reikalų ministro laiškas Lietuvos atstovui Šveicarijoje V. Sidzikauskui. LCVA, f. 383, ap. 7, b. 257, 1. 39-39a; 41a.

84 Stojanovskis turèjo komiso parduotuvę „Occasion“ Konstantinopolyje. Joje supirkdavo iš pabėgèlių daiktus. Vieną dieną jis uždarè parduotuvę ir dingo su visais pabėgèliu daiktais. Žiniai apie jo pabėgimą pasklidus Paryžiuje rusų laikraščiuose buvo mestas šešèlis ir lietuviams. Žr.: 1922 m. balandžio (pranešime data nenurodyta) V. Sidzikausko pranešimas URM apie misiją Turkijoje, Jugoslavijoje ir Bulgarijoje. LCVA, f. 383, ap. 7, b. $257,1.11$.

$851922 \mathrm{~m}$. balandžio (pranešime data nenurodyta) V. Sidzikausko pranešimas URM apie misiją Turkijoje, Jugoslavijoje ir Bulgarijoje. LCVA, f. 383, ap. 7, b. 257, 1. 11. 
igaliojęs ją vežioti jiems laiškus, pinigus bei siuntinius“, buvo pranešęs Antantès šalių aukštiesiems komisarams Konstantinopolyje ir pašęs leisti draugijai tuos darbus atlikti. Leidimas buvo gautas ${ }^{86}$.

\subsubsection{Bendradarbiavimas su Antantès aukštaisiais komisarais}

Kpt. B. Blaveščiūnas Konstantinopolyje kreipèsi i Antantès šalių aukštuosius komisarus, prašydamas pripažinti Komitetą Konstantinopolyje ir suteikti jam pagalbą reevakuojant ir repatrijuojant Lietuvos piliečius. 1920 m. lapkričio 20 d. pranešime Lietuvos URM kpt. B. Blaveščiūnas minejjo, kad Komitetui Konstantinopolyje pavyko susitarti su aukštuoju Italijos komisaru, kad praleistų grupę lietuvių, vykstančių jūra per Triestą í Lietuvą „savo jègomis“. Už jų kelionę turèjo būti sumokèta labdaringų organizacijų lěšomis, kurių prašyti i̇sipareigojo Komitetas Konstantinopolyje. Kelionejje pabėgèlius turèjo maitinti Raudonojo Kryžiaus organizacijos atstovai ${ }^{87}$. Kpt. B. Blaveščiūnas prašè JAV aukštąji komisarą globoti Komitetą Konstantinopolyje ${ }^{88}$. Tačiau jau po savaitès paaiškèjo, kad kelionè per Triestą negalima. $1920 \mathrm{~m}$. lapkričio 27 d. B. Blaveščiūnas iš Italijos konsulato Konstantinopolyje gavo memorandumą, kad lietuvių pabėgèlių repatriacija per Triestą yra uždrausta. Klausė Lietuvos URM, ką tokioje kritiškoje situacijoje daryti ${ }^{89}$.

Draudimas vykti per Triestą buvo atšauktas. $1921 \mathrm{~m}$. sausio 9 d. Italijos generalinis komisaras Trieste pranešė Italijos vyriausybès igaliotiniui Kaune, kad yra 500 lietuvių kilmès pabėgèlių, kuriems išduoti Komiteto Konstantinopolyje pasai ${ }^{90} .1921 \mathrm{~m}$. sausio $16 \mathrm{~d}$. Italijos igaliotinis Lietuvoje Umberto Sala Lietuvos URM pranešè, kad iš generolo de la Venetie Julienne sužinojo, jog Lietuvos piliečiai galès grịžti per Triestą ${ }^{91}$.

\footnotetext{
$861922 \mathrm{~m}$. balandžio (pranešime data nenurodyta) V. Sidzikausko pranešimas URM apie misiją Turkijoje, Jugoslavijoje ir Bulgarijoje. LCVA, f. 383, ap. 7, b. 257, 1. 11.

8719201120 B. Blaveščiūno raportas URM apie Lietuvos piliečių komitetą Konstantinopolyje. LCVA, f. 383, ap. 7, b. 214, 1. 68-68a.

88 Ten pat.

8919201127 B. Blaveščiūno laiškas URM. LCVA, f. 383, ap. 7, b. 214, 1. 70-71.

9019210109 Italijos igaliotiniui Lietuvoje. LCVA, f. 383, ap. 7, b. 214, 1. 64.

9119210116 Italijos igaliotinio Lietuvoje Umberto Sala pranešimas URM. LCVA, f. 383,
} 


\subsection{Komiteto Konstantinopolyje pirmininko tapsmas Lietuvos vyriausybès igaliotiniu (1921 m. sausio 19-1921 m. vasario $28 \mathrm{~d}$.)}

1921 m. sausio mèn. Lietuvos užsienio reikalų ministerija, noredama leisti veikti kpt. B. Blaveščiūnui Lietuvos Respublikos vyriausybės vardu, siekiant ginti Lietuvos piliečių interesus, tikrino kpt. B. Blaveščiūno pranešime (rašytame $1920 \mathrm{~m}$. lapkričio 20 d.) URM pateiktą informaciją apie Komiteto Konstantinopolyje narius ir ypač jo pirmininką. Užsienio reikalų ministerija užklausė Krašto apsaugos ministerijos ${ }^{92}$, o pastaroji - Panevéžio komendanto ${ }^{93}$, ar gauta informacija apie jo kilmę iš Panevėžio yra tikra. Jokių duomenų apie B. Blaveščiūną iš Panevèžio komendanto negauta ${ }^{94}$.

$1921 \mathrm{~m}$. sausio $17 \mathrm{~d}$. Lietuvos URM iš Lietuvos atstovo Londone A. Tiškevičiaus gavo Didžiosios Britanijos URM užklausą, ar Lietuvos vyriausybė sutinka suderinti ir apmokèti 19 Lietuvos piliečių, evakuotų iš Krymo (septyni iš jų su šeimomis, turintys Lietuvių komitetų Sevastopolyje, Simferopolyje ir Konstantinopolyje išduotus liudijimus), prašiusių Didžiosios Britanijos aukštojo komisaro Konstantinopolyje pagalbos grịžti ị Lietuvą, repatrijavimo išlaidas ${ }^{95}$. Kiek vẻliau, $1921 \mathrm{~m}$. sausio 29 d., informacija apie lietuvių kilmès karininkus su šeimomis iš gen. ltn. P. Vrangelio armijos Konstantinopolyje URM buvo gauta ir iš Prancūzijos komisaro Baltijos valstybèse Gabrieliaus Padovani ${ }^{96}$.

Didžiosios Britanijos užklausa paskatino URM viceministrą Petrą Klimą $1921 \mathrm{~m}$. sausio $18 \mathrm{~d}$. išsiųsti laišką Lietuvos pasiuntinybei Vokietijoje ir prašyti telegrama perduoti kpt. B. Blaveščiūnui igaliojimą išduoti Lietuvos piliečiams Konstantinopolyje laikinus pažymejjimus, kurie padètų grị̌ži ị Lietuvą $^{97}$. Nurodyta, kad Lietuvos piliečiais galima laikyti asmenis, gimu-

\footnotetext{
ap. 7, b. 214, 1. 63 .

9219210118 KAM telegrama J. Šauliui (URM). LCVA, f. 383, ap. 7, b. 214, 1. 54.

9319210116 Panevėžio komendanto kpt. Chodokausko telegrama KAM ministro padèjejui. LCVA, f. 383, ap. 7, b. 214, 1. 55.

94 Ten pat.

9519210117 A. Tiškevičiaus Lietuvos atstovo Londone Lietuvos URM persiųstas Foreign Office laiškas. LCVA, f. 383, ap. 7, b. 214, 1. 48.

9619210129 G. Padovani raštas Lietuvos URM. LCVA, f. 383, ap. 7, b. 214, 1. 49.

9719210121 P. Klimo telegrama Lietuvos pasiuntinybei Berlyne, kuri turèjo būti per-
} 
sius Lietuvoje, ir tuos, kurie gyveno Lietuvoje 10 metų prieš karą, išskyrus Rusijos tarnautojus (valdininkus). Lietuvos teritorija prašo laikyti senąją Kauno guberniją ir Suvalkų guberniją be Suvalkų ir Augustavo apskričių, taip pat Vilniaus guberniją be Dysnos ir Vileikos apskričių ${ }^{98}$. Lietuvos pasiuntinybė Vokietijoje ministerijos laišką dèl iggaliojimų B. Blaveščiūnui suteikimo gavo sausio $20 \mathrm{~d}$., tačiau telegramos tą dieną išsiųsti nebespejo. Telegrama į Konstantinopolị buvo išsiųsta tik $1921 \mathrm{~m}$. sausio $21 \mathrm{~d} .{ }^{99}$ Informacija apie Lietuvos vyriausybės iggaliotinio Turkijoje paskyrimą $1921 \mathrm{~m}$. vasario $12 \mathrm{~d}$. buvo paskelbta ir dienraštyje „Lietuva“ ${ }^{100}$.

Suteikęs kpt. B. Blaveščiūnui igaliojimą išduoti Lietuvos piliečiams Konstantinopolyje laikinus pažymėjimus, kurie padètų grị̌ži ì Lietuvą, viceministras $\mathrm{P}$. Klimas paprašė užsienio reikalų ministro Juozo Purickio kreiptis ị Amerikos Raudonajj Kryžių, kad padètų Lietuvos piliečiams grị̌ti i tèvynę. Lietuvos vyriausybe ịsipareigojo padengti išlaidas ${ }^{101}$. Užsienio reikalų ministerijos viceministras $1921 \mathrm{~m}$. vasario $9 \mathrm{~d}$. prašè ir Lietuvos atstovo Rygoje Dovo Zauniaus kreiptis ị Amerikos Raudonąji Kryžių pagalbos (kad jis apsiimtų pagal liudijimus išduoti pašalpą grị̌tantiems ị Lietuvą) $)^{102}$.

URM kpt. B. Blaveščiūnui suteikti iggaliojimai rūpintis Lietuvos piliečiais Turkijoje dar kartą pakartoti $1921 \mathrm{~m}$. vasario $9 \mathrm{~d}$. telegramoje tiesiai $\mathfrak{i}$ Konstantinopoli $\mathfrak{i}^{103}$. Apie igaliotinio Turkijoje paskyrimą pranešta ir kitoms Lietuvos atstovybėms Vokietijoje, Latvijoje, Anglijoje, Paryžiuje, Romoje, taip pat Antantès šalių igaliotiniams Kaune. Per juos ir buvo palaikomas nuolatinis ryšys su aukštaisiais komisarais Konstantinopolyje. Lietuvos URM 1921 m. vasario 9 d. padèkojo G. Padovani už informaciją

siųsta ị Konstantinopolị. LCVA, f. 383, ap. 7, b. 214, 1. 59.

9819210209 P. Klimo telegrama į Konstantinopolį B. Blaveščiūnui. LCVA, f. 383, ap. 7, b. $214,1.53$. Tas pat prancūzų kalba. LCVA, f. 383, ap. 7, b. 214, 1. 60.

9919210122 V. Gailiaus, einančio Lietuvos atstovo Vokietijoje pareigas, pranešimas URM viceministrui P. Klimui. LCVA, f. 383, ap. 7, b. 214, 1. 58.

${ }^{100}$ Lietuvių vargai Konstantinopoly. Lietuva, 192102 12, Nr. 34, p. 3.

10119210209 ranka rašytas užrašas (autorius nenurodytas). LCVA, f. 383, ap. 7, b. 214, 1. 46.

10219210209 LR URM viceministro raštas Lietuvos atstovui Rygoje D. Zauniui. LCVA, f. 383 , ap. 7 , b. $214,1.50$.

10319210209 P. Klimo telegrama ị Konstantinopoli B. Blaveščiūnui. LCVA, f. 383, ap. 7, b. $214,1.53$. Tas pat prancūzų kalba. LCVA, f. 383, ap. 7, b. 214, 1. 60. 
iš Konstantinopolio ir prašè perduoti Prancūzijos aukštajam komisarui Konstantinopolyje, kad Lietuva paskyrė Komiteto Konstantinopolyje pirmininką kpt. B. Blaveščiūną, kuris turès perimti Lietuvos piliečių globą ir išduoti laikinus liudijimus, kad jie galètų grị̌ti i t Lietuvą ${ }^{104}$. B. Blaveščiūnas buvo prašęs Lietuvos vyriausybès pagalbos komunikuojant su Prancūzijos aukštuoju komisaru Konstantinopolyje.

Nuo $1921 \mathrm{~m}$. vasario $9 \mathrm{~d}$. prasidejo naujas kpt. B. Blaveščiūno - Lietuvos vyriausybès igaliotinio Turkijoje (Delegue du Gouvernement de Lithuanie) - veiklos laikotarpis. Lietuvos užsienio reikalų ministras $1921 \mathrm{~m}$. gegužès 4 d. laiške kpt. B. Blaveščiūnui skyrè „gilios padèkos žodžius“ už „visus gerus darbus ir stropų pasidarbavimą, kurị atlikote Lietuvos interesuose“ ir skubejo „podraug išreikšti viltį, kad savo patyrimu Tamsta ir toliau neatsisakysite patarnauti Tẻvynei jos sunkiame darbe "105.

Apibendrinant galima būtų teigti, kad Komiteto Konstantinopolyje ịsteigimą lèmé sutampantys interesai: viešasis - Turkijoje atsirado Lietuvos piliečių, kuriems reikèjo jų interesams atstovaujančios institucijos, kad prireikus jiems išduotų Europos šalyse pripažistamus dokumentus ir pasirūpintų jų apgyvendinimu, maitinimu, repatriacija ar reevakuacija, ir privatus - čia buvo ir P. Vrangelio armijos karininkų be dokumentų, su kuriais juos ịleistų Europos valstybės. Komitetas Konstantinopolyje turèjo atlikti keletą funkcijų: komunikacinę - susisiekti su Lietuvos vyriausybe, Turkijos valdžia ir Antantès aukštaisiais komisarais, socialinępasirūpinti lietuvių pabėgèlių gyvenamąja vieta ir maitinimu, taip pat konsulinę - išduoti dokumentus ir ginti Lietuvos piliečių interesus.

\footnotetext{
10419210209 LR URM viceministro raštas Prancūzijos igaliotiniui Lietuvoje G. Padovani. LCVA, f. 383, ap. 7, b. 214, 1. 51.

10519210504 URM valdytojo, einančio ministro pareigas, laiškas kpt. B. Blaveščiūnui. LCVA, f. 383, ap. 7, b. 214, 1. 38.
} 


\section{KONSULINIS ATSTOVAVIMAS LIETUVOS PILIEČIAMS TURKIJOJE IR JUGOSLAVIJOJE NUO 1921 M. VASARIO 9 D. IKI VYR. LTN. J. MACEVIČIAUS ATVYKIMO}

Informacija apie kpt. B. Blaveščiūno paskyrimą $1921 \mathrm{~m}$. vasario $9 \mathrm{~d}$. Lietuvos vyriausybès igaliotiniu Turkijoje Konstantinopoli pasiekè ne iš karto. Telegrama iš Kauno ị Konstantinopolị nukeliaudavo per 24-28 valandas ${ }^{106}$, tačiau $1921 \mathrm{~m}$. vasario $12 \mathrm{~d}$. Prancūzijos aukštojo komisaro Konstantinopolyje dar nebuvo pasiekusi ${ }^{107}$. Paaiškejjo, kad 1921 m. vasario 9 d. notos, įteiktos G. Padovani, turinys apie kpt. B. Blaveščiūno paskyrimą Prancūzijos aukštajam komisarui Konstantinopolyje vasario $12 \mathrm{~d}$. dar nebuvo žinomas, todèl kpt. B. Blaveščiūno išduotų laikinų liudijimų lietuvių tremtiniams nepripažino Prancūzijos aukštasis komisaras Konstantinopolyje ir nedavė leidimų jiems išvykti. Kpt. B. Blaveščiūnas $1921 \mathrm{~m}$. vasario $12 \mathrm{~d}$. telegramoje Lietuvos užsienio reikalų ministerijai aiškino, kad Komitetas Konstantinopolyje negali padèti leidimų išvykti laukiantiems lietuviams tremtiniams, nes neturi galimybès telegrafu persiųsti Prancūzijos aukštajam komisarui Konstantinopolyje Lietuvos vyriausybės jam suteiktų igaliojimų ir pranešti apie paskyrimą ${ }^{108}$. Taigi reikèjo sulaukti oficialaus rašto arba iš Italijos atstovo Lietuvoje, arba iš Lietuvos pasiuntinybès Vokietijoje, per kurią buvo komunikuojama persiunčiant informaciją i Konstantinopolị. Atsitiktinai ar ne, tačiau tą pačią dieną (vasario 12-ąją) dienraštis „Lietuva“ užsiminè, kad ị Lietuvą „iš Konstantinopolio su specialiu raportu“ atvyksta inžinierius Petras Vileišis ${ }^{109}$. Jis ir padejjo Lietuvos vyriausybès igaliotiniui kpt. B. Blaveščiūnui bendrauti su Prancūzijos aukštuoju komisaru Konstantinopolyje ${ }^{110}$. V. Sidzikausko

\footnotetext{
10619210827 J. Macevičiaus pranešimas užsienio reikalų ministrui. LCVA, f. 383, ap. 7, b. $257,1.45$.

10719210212 B. Blaveščiūno telegrama iš Konstantinopolio Lietuvos URM. LCVA, f. 383, ap. 7 , b. $214,1.52-52$ a.

108 Ten pat.

${ }^{109}$ Lietuvių vargai Konstantinopoly. Lietuva, 192102 12, Nr. 34, p. 3.

${ }^{110}$ Iš Kaukazo į Lietuvą. Lietuva, 192102 26, Nr. 45, p. 2.
} 
ataskaitoje apie Lietuvos konsulinès atstovybės Konstantinopolyje uždarymą minima $1921 \mathrm{~m}$. vasario $28 \mathrm{~d}$. data, nuo kurios kpt. B. Blaveščiūnas laikomas Lietuvos vyriausybès igaliotiniu Turkijoje ${ }^{111}$.

\subsection{Lietuvos vyriausybès ịgaliotinio konsulinè veikla ir lèšų lietuvių pabẻgẻlių išlaikymui ir grąžinimui paieška}

Kpt. B. Blaveščiūnui kartu su igaliojimais $1921 \mathrm{~m}$. vasario $9 \mathrm{~d}$. buvo atsiųsta ir instrukcija, kuria vadovaujantis turejo būti išduodami pasai, liudijimai, vizos ${ }^{112}$. I Lietuvą pradejo grịžti lietuviai pabègèliai iš Turkijos. Jugoslavijos, Vokietijos ir Austrijos atstovybių Konstantinopolyje nebuvo, todèl vykstantieji ị Lietuvą su Konstantinopolyje išduotais dokumentais „užkliūdavo“ Jugoslavijoje. Norẻdamas išspręsti šią problemą ir palengvinti grị̌ǐimą per Jugoslaviją, kpt. B. Blaveščiūnas 1921 m. vasario mèn. pasiuntė plk. Algirdą Benjaševičių, kpt. Leopoldą Lippingą ir ltn. Anatolijų Pokramovičių i Belgradą (apie tai išsamiau 3.2 skyriuje) ${ }^{113}$.

$1921 \mathrm{~m}$. vasario pabaigoje Lietuvą pasiekę lietuviai pabėgèliai (civiliai) parvyko maršrutu Konstantinopolis-Sofija-Belgradas-PrahaBerlynas-Kaunas ${ }^{114}$. Šiuo maršrutu grịžo ir P. Vileišis. Grịžęs ị Lietuvą, plk. Banevičius (vardas autorei nežinomas) Užsienio reikalų ministerijos Politikos departamento direktoriui B. K. Balučiui nurodè tikslesnị maršrutą: Konstantinopolis-Svilengradas-Sofija-Zarebrodas-Belgradas-Zagrebas-Mariboras-Viena-Pasau-Berlynas-Kaunas ${ }^{115}$, kuriuo parvyko kariškiai, ir šio maršruto išlaidas (žr. 2 lentelę). Kaip matyti iš 2 lentelèje pateiktų duomenų, kelionès nuo Svilengrado iki Belgrado ir nuo Vienos iki Berlyno išlaidas padengė Rusijos ir Tarptautinis Raudonasis Kryžius.

1111922 m. balandžio (pranešime data nenurodyta) V. Sidzikausko pranešimas URM apie misiją Turkijoje, Jugoslavijoje ir Bulgarijoje. LCVA, f. 383, ap. 7, b. 257, 1. 10-11.

11219211104 užsienio reikalų ministro laiškas Lietuvos atstovui Šveicarijoje V. Sidzikauskui. LCVA, f. 383, ap. 7, b. 257, 1. 39.

${ }^{113} 1922$ m. balandžio (pranešime data nenurodyta) V. Sidzikausko pranešimas URM apie misiją Turkijoje, Jugoslavijoje ir Bulgarijoje. LCVA, f. 383, ap. 7, b. 257, 1. 3.

114 Iš Kaukazo ị Lietuvą. Lietuva, 192102 26, Nr. 45, p. 2.

11519210303 URM PDD direktoriaus B. K. Balučio pro memoria (apie Lietuvių komitetą ir lietuvių tremtinius Konstantinopolyje). LCVA, f. 383, ap. 7, b. 214, 1. 41. 
2 lentelè. Kariškio kelionès iš Konstantinopolio ị Lietuvą išlaidos kiekvienoje atkarpoje

\begin{tabular}{|c|c|}
\hline Kelionès atkarpa & Pinigų suma už kelionès atkarpą \\
\hline $\begin{array}{l}\text { Konstantinopolis- } \\
\text { Svilengradas }\end{array}$ & 6 Turkijos liros (apie 120 auksinų) \\
\hline Svilengradas-Sofija & $\begin{array}{l}\text { Kelionė nekainuoja, nes veža Rusijos Raudonasis Kryžius (už } \\
\text { tai buvo atsakinga Rusijos pasiuntinybe Konstantinopolyje, } \\
\text { konkrečiai - generolas Konstantinas Globočevas (Константин } \\
\text { Глобачев). }\end{array}$ \\
\hline Sofija-Zarebrodas & Kelionė nekainuoja, nes veža Rusijos Raudonasis Kryžius. \\
\hline $\begin{array}{l}\text { Zarebrodas- } \\
\text { Belgradas }\end{array}$ & Kelionė nekainuoja, nes veža Rusijos Raudonasis Kryžius. \\
\hline Belgradas-Zagrebas & $\begin{array}{l}\text { Kelionė nekainuoja, nes veža P. Vrangelio buvusios vyriausybės } \\
\text { igaliotinis Smirnovas (vardas autorei nežinomas). }\end{array}$ \\
\hline Zagrebas-Mariboras & 10 dinarų \\
\hline Mariboras-Viena & 115 Austrijos kronų (11 auksinų) \\
\hline Viena-Pasau & Kelionė nekainuoja, nes veža Rusijos Raudonasis Kryžius. \\
\hline Pasau-Berlynas & Kelionè nekainuoja, nes veža Tarptautinis Raudonasis Kryžius. \\
\hline
\end{tabular}

Sudaryta autorès remiantis: 19210303 URM PDD direktoriaus B. K. Balučio pro memoria (apie Lietuvių komitetą ir lietuvių tremtinius Konstantinopolyje). LCVA, f. 383, ap. 7, b. $214,1.41$.

1921 m. kovo 12 d. kpt. B. Blaveščiūnas i Kauną išsiuntė diplomatinị kurjerị - Komiteto Konstantinopolyje narị Solomoną Geselsoną ${ }^{116}$, o $1921 \mathrm{~m}$. balandžio $13 \mathrm{~d}$. telegrama pranešè, kad „visi repatriacijos keliai uždaryti, visuomeninès organizacijos atsisako padèti, visi pabėgèliai, norintys vykti per Europą, turi prašyti Tarptautinio Raudonojo Kryžiaus pagalbos. Vyriausybė turi garantuoti pinigų Raudonajam Kryžiui grąžinimą"117.

Apie sunkią lietuvių pabėgèlių padètị Konstantinopolyje bylojo ir kan. Jurgio Narjausko - Lietuvos atstovo prie Šventojo Sosto - $1921 \mathrm{~m}$. balandžio $10 \mathrm{~d}$. URM atsiųstas pranešimas. Jame J. Narjauskas teigia, kad iš kongregacijos „Orientalium“ asesoriaus arkivyskupo Papadopulos

11619210312 igaliojimas Solomonui Hesselsonui atlikti diplomatinio kurjerio pareigas. LCVA, f. 383, ap. 7, b. 214, 1. 26.

11719210413 kpt. B. Blaveščiūno telegrama URM. LCVA, f. 383, ap. 7, b. 214, 1. 23-23a. 
sužinojo apie 100 iš Tifliso ị Konstantinopoli patekusių lietuvių, kurie „neturi pinigų, maisto ir kur prisiglausti“. Šv. Velykų proga jiems buvo „padalinta pinigų“, vèliau dar šiek tiek atsiųsta kongregacijos, tačiau vis tiek jų buvo per mažai. Siūlè kongregacijos pagalbą išrūpinant lietuviams, pasiruošusiems grižti ị Lietuvą, Italijos valdžios leidimą vykti garlaiviu nuo Konstantinopolio iki Neapolio, tačiau J. Narjauskas sakẻ turịs atsiklausti Lietuvos vyriausybès. Apie Lietuvos vyriausybės paskirtą igaliotinị kpt. B. Blaveščiūną neužsiminè $\dot{1}^{118}$.

Iš telegramos teksto ir J. Narjausko pranešimo URM galima numanyti, kad Lietuvos vyriausybès igaliotiniui labai reikejo URM kreditų tolesnei veiklai plètoti, nes 1920 m. pabaigoje Komiteto Konstantinopolyje surinktos lèšos baigèsi. Taip pat reikèjo Lietuvos vyriausybès garantijų, kad už pabègèlių grị̌imą sumokèti pinigai bus grąžinti. Tačiau Lietuvos vyriausybė neskubèjo užsikrauti sunkios finansinès naštos - teikti garantijų, prieš tai neįsitikinusi, ar tikrai visi grịžtantieji yra Lietuvos piliečiai ir ar jų pasai gauti teisètai, t. y. pateikus tinkamus, jų lietuvišką kilmę i̇rodančius, dokumentus. Ittarimus sustiprino Lietuvos užsienio reikalų ministerijos Politikos departamento direktoriaus B. K. Balučio pokalbis su iš Turkijos grị̌usiu plk. Banevičiumi. Sužinota apie Komiteto Konstantinopolyje narių A. Millerio ir J. Abramovičiaus veiklą - nelegaliai išduodamus Lietuvos pasus, liudijimus ir vizas. Dèl to Komitetas Konstantinopolyje buvo praradęs Prancūzijos aukštojo komisaro pasitikèjimą ${ }^{119}$. Padètị imta taisyti kpt. B. Blaveščiūnui gavus igaliojimus ir anuliavus 161 Komiteto Konstantinopolyje išduotą pasą bei apie tai pranešus Antantès šalių aukštiesiems komisarams Konstantinopolyje ${ }^{120}$.

URM kreditų kpt. B. Blaveščiūnui ministerija siųsti taip pat neskubejo. B. K. Balutis buvo linkęs paklausyti plk. Banevičiaus patarimo sukurtuosius komitetus panaikinti ir nusiųsti $\mathfrak{i}$ Turkiją, Bulgariją ir Jugoslaviją specialų igaliotinị, kuris padètų surinkti ir $\mathfrak{i}$ Lietuvą pargabenti

\footnotetext{
11819210410 kan. J. Narjausko pranešimas URM. LCVA, f. 383, ap. 7, b. 160, 1. 65.

11919210303 URM PDD direktoriaus B. K. Balučio pro memoria (apie Lietuvių komitetą ir lietuvių tremtinius Konstantinopolyje). LCVA, f. 383, ap. 7, b. 214, 1. 39.

${ }^{120} 1922 \mathrm{~m}$. balandžio (pranešime data nenurodyta) V. Sidzikausko pranešimas URM apie misiją Turkijoje, Jugoslavijoje ir Bulgarijoje. LCVA, f. 383, ap. 7, b. 257, 1. 11.
} 
šiose šalyse likusius Lietuvos piliečius ${ }^{121}$. Šią mintị plk. Banevičius pasiūlè neatsitiktinai. Latvija pabėgèliams ir tremtiniams iš Vidurio Europos šalių, Turkijos ir Užkaukazès grąžinti nuo 1920 m. liepos 2 d. buvo išsiuntusi specialų Latvijos vyriausybès igaliotinị kpt. Aleksandrą Kacensą ir jo broli Konradą Kacensą. Jų misija baigèsi $1921 \mathrm{~m}$. balandžio 22 d. ${ }^{122}$ $1921 \mathrm{~m}$. balandžio $15 \mathrm{~d}$. Lietuvos URM jau buvo apsisprendusi siųsti specialų îgaliotinị vyr. ltn. J. Macevičių ir telegrama apie tai pranešė Lietuvos atstovui Londone pabrěždama, kad, „kol neturime tinkamo atstovo, negalime sutikti grąžinti lèšas. Lauksime Macevičiaus pranešimo“123.

\subsection{Lietuvos Respublikos piliečių taryba Belgrade}

Komiteto Konstantinopolyje 1921 m. vasario mèn. ił Belgradą deleguoti plk. A. Benjaševičius, kpt. L. Lippingas ir ltn. A. Pokramovičius turejo užmegzti ryšius su Jugoslavijos vyriausybe ir gauti jos sutikimą organizuoti lietuvių pabėgèlių ir tremtinių grąžinimą ${ }^{124}$. Deleguoti asmenys buvo subordinuoti Komiteto Konstantinopolyje pirmininkui ir turejo vadovautis kpt. B. Blaveščiūno jiems duotomis instrukcijomis ${ }^{125}$. Darbo pradžiai Belgrade delegatams buvo skirta tam tikra pinigų suma (kokia konkrečiai, šaltiniuose nenurodoma) ${ }^{126}$.

Vasario pabaigoje paaiškèjo, kad kpt. B. Blaveščiūno deleguoti asmenys jo instrukcijų nesilaikè. Jie Belgrade ịkūrẻ Lietuvos Respublikos piliečių tarybą (pirmininkas - plk. A. Benjaševičius, nariai - kpt. Leonidas Lippingas, ltn. A. Pokramovičius ir du ị atsargą išleisti kareiviai ${ }^{127}$ ) ir, pa-

\footnotetext{
12119210303 URM PDD direktoriaus B. K. Balučio pro memoria (apie Lietuvių komitetą ir lietuvių tremtinius Konstantinopolyje). LCVA, f. 383, ap. 7, b. 214, 1. 40.

${ }^{122}$ Lerhe A. Latvijas Respublikas ārlietu dienests 1918-1941. Rīga, 2005, lpp. 143-144.

12319210415 B. K. Balučio telegrama Lietuvos atstovui Londone. LCVA, f. 383, ap. 7, b. $214,1.43$.

${ }^{124} 1922 \mathrm{~m}$. balandžio (pranešime data nenurodyta) V. Sidzikausko pranešimas URM apie misiją Turkijoje, Jugoslavijoje ir Bulgarijoje. LCVA, f. 383, ap. 7, b. 257, 1. 3.

12519211104 užsienio reikalų ministro laiškas Lietuvos atstovui Šveicarijoje V. Sidzikauskui. LCVA, f. 383, ap. 7, b. 257, 1. 40.

1261922 m. balandžio (pranešime data nenurodyta) V. Sidzikausko pranešimas URM apie misiją Turkijoje, Jugoslavijoje ir Bulgarijoje. LCVA, f. 383, ap. 7, b. 257, 1. 3.

12719210303 URM PDD direktoriaus B. K. Balučio pro memoria (apie Lietuvių komitetą
} 
dedami gen. ltn. P. Vrangelio ir Rusijos atstovybès Belgrade, gavo Jugoslavijos vyriausybès sutikimą veikti ir išduoti pasus, liudijimus (certificat) ir vizas norintiems vykti į Lietuvą. Lietuvos Respublikos piliečių tarybos dokumentus neretai gaudavo gen. ltn. P. Vrangelio kariuomenès karininkai ir asmenys, nieko bendra neturintys su Lietuva ${ }^{128} .1921 \mathrm{~m}$. vasario 28 d. B. K. Balutis iš laikinai einančio Lietuvos atstovo Berlyne pareigas Viktoro Gailiaus sužinojo, kad Vokietijos pasiuntinybė Belgrade atsisakè vizuoti plk. A. Benjaševičiaus sudarytos Belgrade Lietuvos Respublikos piliečių tarybos išduotus liudijimus ${ }^{129}$.

Plk. A. Benjaševičius prašè Lietuvos vyriausybės pagalbos, o jos nesulaukęs išvyko į Lietuvą, pasiemęs nemažą pinigų sumą, gautą už išduotus pasus ir vizas ${ }^{130} .1921 \mathrm{~m}$. gegužès $2 \mathrm{~d}$. B. K. Balutis išsiuntė telegramą i Romą ir prašè informuoti kpt. B. Blaveščiūną apie plk. A. Benjaševičiaus atvykimą i Kauną ${ }^{131}$. Politikos departamento direktorius norejjo sužinoti, „ar jo reikalai tvarkoje“. Ši frazè galejo reikšti tik viena - ar kpt. B. Blaveščiūnas žino apie plk. A. Benjaševičiaus kelionę i̇ Lietuvą, t. y. ar jis kontroliuoja situaciją. Lietuvos Respublikos piliečių tarybos pirmininkas tikejjosi, kad URM apmokès jo kelionès išlaidas ir viešbučio sąskaitą, tačiau ministerija neskubejjo to daryti, kol „nebus išaiškintas bendras Belgrado lietuvių „konsulato“ klausimas“132. Laukdamas atsakymo iš URM plk. A. Benjaševičius išvyko pas tèvus ị Gražiškị, o vèliau - ił Lenkijos okupuotą Vilnių ${ }^{133}$.

ir lietuvių tremtinius Konstantinopolyje). LCVA, f. 383, ap. 7, b. 214, 1. 41.

${ }^{128} 1922$ m. balandžio (pranešime data nenurodyta) V. Sidzikausko pranešimas URM apie misiją Turkijoje, Jugoslavijoje ir Bulgarijoje. LCVA, f. 383, ap. 7, b. 257, 1. 3.

12919210303 URM PDD direktoriaus B. K. Balučio pro memoria (apie Lietuvių komitetą ir lietuvių tremtinius Konstantinopolyje). LCVA, f. 383, ap. 7, b. 214, 1. 41.

${ }^{130} 1922 \mathrm{~m}$. balandžio (pranešime data nenurodyta) V. Sidzikausko pranešimas URM apie misiją Turkijoje, Jugoslavijoje ir Bulgarijoje. LCVA, f. 383, ap. 7, b. 257, 1. 3.

${ }^{131} 19210502$ B. K. Balučio telegrama Lietuvos atstovybei Romoje. LCVA, f. 383, ap. 7, b. $214,1.36$.

13219210509 URM paaiškinimas dèl. plk. A. Benjaševičiaus sąskaitų apmokèjimo. LCVA, f. 383 , ap. 7 , b. $214,1.27$.

${ }^{133} 1922 \mathrm{~m}$. balandžio (pranešime data nenurodyta) V. Sidzikausko pranešimas URM apie misiją Turkijoje, Jugoslavijoje ir Bulgarijoje. LCVA, f. 383, ap. 7, b. 257, 1. 3. 


\subsection{Lietuvos vyriausybės igaliotinio paskyrimas ir konsulinès atstovybès įsteigimas Belgrade}

Išvykus plk. A. Benjaševičiui, Lietuvos Respublikos piliečių tarybos pirmininku tapo kpt. Leonidas Lippingas. Jị kpt. B. Blaveščiūnas $1921 \mathrm{~m}$. gegužès 7 d. raštu (Nr. 362) paskyrè Lietuvos vyriausybès igaliotiniu Jugoslavijoje ir davè leidimą išduoti liudijimus (certificat) ị Lietuvą grị̌žtantiems pabègéliams ${ }^{134}$. Savo sprendimą apie kpt. L. Lippingo skyrimą Lietuvos vyriausybès igaliotiniu Jugoslavijoje kpt. B. Blaveščiūnas notifikavo Vokietijos pasiuntinybei Belgrade ir prašè vizuoti jo išduotus pasus per Vokietiją i Lietuvą vykstantiems asmenims ${ }^{135}$. Oficialus kpt. L. Lippingo pareigu pavadinimas buvo „laikinasis Lietuvos Respublikos vyriausybės igaliotinis Jugoslavijoje ir Lietuvos Respublikos piliečių tarybos Jugoslavijoje pirmininkas" („délégué temporaire en Royaume des Serbes, Croates et Slovènes par le déléguè du Gouvernement de la Republique de Lithuanie et président du Taryba des citoyens de la Republique de Lithuanie en Royaume de des Serbes, Croates et Slovènes“") ${ }^{136}$. Naujasis igaliotinis Jugoslavijoje išduodavo pasus ir vizas vykstantiems ị Lietuvą pabėgèliams, teikè žinias apie Lietuvą Belgrado spaudai ir Jugoslavijos užsienio reikalų ministerijai, mezgè ryšius su kitų šalių atstovais Belgrade, polemizavo spaudoje „su lenkais dèl Vilniaus“137.

1341922 m. balandžio (pranešime data nenurodyta) V. Sidzikausko pranešimas URM apie misiją Turkijoje, Jugoslavijoje ir Bulgarijoje. LCVA, f. 383, ap. 7, b. 257, 1. 3-4.

$1351922 \mathrm{~m}$. balandžio (pranešime data nenurodyta) V. Sidzikausko pranešimas URM apie misiją Turkijoje, Jugoslavijoje ir Bulgarijoje. LCVA, f. 383, ap. 7, b. 257, 1. 4.

136 Ten pat.

137 Ten pat. 


\section{VYR. LTN. JUOZO MACEVIČIAUS MISIJA BALKANŲ ŠALYSE IR TURKIJOJE (1921 M. GEGUŽ̇̇-RUGSĖJIS)}

\subsection{Juozo Macevičiaus paskyrimas}

1921 m. sausio mèn. Lietuvos pasiuntinybei prie Šventojo Sosto prireikè sekretoriaus, mokančio italų kalbą. Kanauninkas dr. Jurgis Narjauskas 1921 m. sausio 19 d. papraše Užsienio reikalų ministerijos „išrūpinti paliuosavimą nuo dabartinių pareigų artilerijos 3-io bataliono ltn. p. Macevičiui“, kuriam planavo siūlyti atstovybès sekretoriaus pareigas ${ }^{138}$. J. Macevičius buvo baigęs Odesos miesto 1-ąją gimnaziją, Odesos dailès mokyklą, Fotografijos technikos kursus, privačiai mokęsis tapybos, taip pat baigęs Artilerijos mokyklą (igijęs karininko laipsnị), Novorosijsko (dabar - Odesos) universiteto Teisès fakulteto 3 kursus ir Odesos politechnikumo Statybos skyriaus I kursą. Turejo ir tarnautojo darbo patirties - dirbo Odesos miesto savivaldybès raštinejje (1914 m.), „Zemskij sojuz“valdyboje sekretoriumi (1916 m.), Raudonojo Kryžiaus valdyboje Odesoje sekretoriumi (1918 m.), dalyvavo kare - 1916 m. kovojo Rumunijos fronte (paskirtas „Vyresniuoju baterijos karininku“), nuo 1919 m. gruodžio $6 \mathrm{~d}$. tarnavo Lietuvos kariuomeneje Artilerijos brigados komendantu (iki 1920 m. birželio 1 d.), nuo 1920 m. birželio 1 d. - „baterijos vyresniuoju karininku Daugpilio, Seinų ir Vilniaus fronte “139. Užsienio reikalų ministerija nusprendè patenkinti kan. J. Narjausko prašymą ir dèl to kreipèsi į KAM. $1921 \mathrm{~m}$. balandžio $5 \mathrm{~d}$. vyresnysis leitenantas Juozas Macevičius buvo „laikinai paleistas" iš kariuomenès ir tapo pavaldus URM ${ }^{140}$.

Dar iki KAM sutikimo paskirti vyr. ltn. J. Macevičių URM žinion 1921 m. kovo 3 d. Politikos departamento direktorius B. K. Balutis nusprendè J. Macevičiaus kelionès ị Vatikaną maršrutą pasukti per Konstantinopolị, Sofiją ir Belgradą („likvidavimui minètų komitetų, sutvè-

\footnotetext{
13819210119 M. Narjausko laiškas URM. LCVA, f. 383, ap. 7, b. 160, 1. 171.

13919211021 Atstovybès prie Šventojo Sosto žinių papildymas. LCVA, f. 383, ap. 7, b. $160,1.8$.

${ }^{140} 19210405$ KAM raštas URM. LCVA, f. 383, ap. 7, b. 214, 1. 20.
} 
rimui naujų (jei būtų tam reikalas) ir išgabenimui Lietuvon atitinkamų ir čia reikalingų žmonių maždaug tokiomis sąlygomis, kaip, pvz., latviai gabena") ${ }^{141}$. Gal sutapimas, o gal ir ne, tačiau specialiai misijai i Turkiją ir Balkanų šalis pasirinktas labai panašios patirties turintis asmuo, kaip ir Latvijoje (Aleksanders Kacens). Baigta karo mokykla, patirtis fronte Pirmojo pasaulinio karo metu, valdininko darbo patirtis, studijos Novorosijsko universitete (Odesoje) ${ }^{142}$.

1921 m. gegužès 2 d. užsienio reikalų ministras paskyrè vyr. ltn. Juozą Macevičių Lietuvos Respublikos vyriausybès igaliotiniu, „turinčiu konsulinius igaliojimus prie Bulgarijos, Turkijos ir Jugoslavijos vyriausybių Lietuvos piliečių grąžinimui su teise deleguoti savo igaliojimus kitiems tinkamiems asmenims“ („Par le present, je sertifie que Monsieur Juozas Macevičius est nomeé Resprésentant ${ }^{143}$ du Gouvernement de la Republique Lithuanienne, chargé de pouvoirs consulaires auprès des Gouvernements de Bulgarie, de Turquie et de Yougo-Slavie pour le rapatriement des citoyens Lithuaniens, avec le droit de déléguer ses pouvoirs à d'autres personnes, selon sa convenance") $)^{144}$. Paskyrimo dieną vyr. ltn. Juozui Macevičiui buvo duota instrukcija, kurioje „pavedama ištirti ir tuojaus Lietuvos vyriausybei pranešti apie padètị Lietuvos piliečių tremtinių, pakliuvusių ị îvairias Balkanų valstybes - Turkiją, Bulgariją, Jugoslaviją"145. Vienas iš misijos uždavinių buvo „nuodugniai susipažinti su ịvairių Lietuvių tremtinių Komitetų ir visų kitokių tam tikslui esančių minètose valstybèse ịstaigų veikla" ir prireikus jas reorganizuoti ar net uždaryti ${ }^{146}$. Suteikta teisè sudaryti naujus komitetus, kurie rūpintųsi tremtinių grąžinimu, arba paskirti igaliotinius. Tokia teisė buvo suteikta todèl, kad Lietuvos užsienio reikalų ministerija nežinojo, kokia yra susiklosčiusi situacija vietoje, todèl pasikliovè igaliotinio nuožiūra. Ministerija tikẻjosi, kad užteks

14119210303 B. K. Balučio pro memoria (apie Lietuvių komitetą ir lietuvių tremtinius Konstantinopolyje). LCVA, f. 383, ap. 7, b. 214, 1. 42.

142 Jēkabsons Ē., Ščerbinskis V. Latvijas ārlietu dienesta darbinieki 1918-1991. Biogrāfiska vārdnīca. Rìga: Zinātne, 2003, p. 148.

143 Žodyne „représentant“ reikšmè (p. 785) - atstovas, ịgaliotinis.

14419210502 Juozo Macevičiaus paskyrimo raštas. LCVA, f. 383, ap. 7, b. 214, 1. 37.

14519210502 B. K. Balučio duota instrukcija J. Macevičiui. LCVA, f. 383, ap. 7, b. 214, 1. $18-19$.

146 Ten pat. 
vieno igaliotinio visoms Balkanų valstybėms ${ }^{147}$. Pargabenant pabėgèlius ministerija patarè bendradarbiauti su visomis tarptautinėmis institucijomis, besirūpinančiomis pabėgèlių grąžinimu - Tarptautiniu Raudonuoju Kryžiumi, „tremtinių komitetais“, kurie galètų suteikti pagalbą grąžinant Lietuvos piliečius ${ }^{148}$.

Antrasis uždavinys - surinkti kuo tikslesnę informaciją apie Lietuvos piliečių skaičių ir padètị. Prašyta surinkti informaciją apie Lietuvos piliečius, kilusius iš: 1) Lietuvos vyriausybès kontroliuojamos teritorijos ir 2) iš tos Lietuvos teritorijos dalies, kuri nustatyta $1920 \mathrm{~m}$. liepos $12 \mathrm{~d}$. sutartimi su Sovietų Rusija. Nustatant Lietuvos piliečių skaičių URM griežtai pareikalavo laikytis „Lietuvos pilietybės įstatymo“ ir vadovautis „ypatingomis instrukcijomis“, kurios buvo duotos Lietuvos atstovybėms užsienyje. Ministerijai vyr. ltn. J. Macevičius turẻjo pranešti kiekvienoje grupejje esančių asmenų skaičių, kiek jų negali grị̌̌ti be valstybės pagalbos, kiek kainuotų vieno asmens pargabenimas, kiek tarp tremtinių yra valstybei „reikalingų specialistų“ ir kiek grịžusiųjų galètų patys susimokèti - atlyginti pargabenimo išlaidas ${ }^{149}$.

Lietuvos užsienio reikalų ministras $1921 \mathrm{~m}$. gegužès 4 d. laiške Prancūzijos aukštajam komisarui Konstantinopolyje pranešè, kad Lietuva pasiuntè ị Turkiją vyr. ltn. Juozą Macevičių kaip Lietuvos Respublikos vyriausybès igaliotinị ir suteikè jam konsulinius igaliojimus organizuoti Lietuvos piliečių, esančių Turkijoje ir norinčių grịžti namo, pargabenimą. Prašè padèti jam vykdyti savo funkcijas ${ }^{150}$. Analogiški užsienio reikalu ministro laiškai buvo išsiųsti Italijos ${ }^{151}$, Didžiosios Britanijos ${ }^{152}$ komisarams Konstantinopolyje, Jugoslavijos užsienio reikalų ministrui Belgra-

\footnotetext{
147 Ten pat, 1. 19.

148 Ten pat.

149 Ten pat, 1. 18.

${ }^{150}$ Lietuvos užsienio reikalų ministro $1921 \mathrm{~m}$. gegužès 4 d. laiškas Prancūzijos aukštajam komisarui Konstantinopolyje. LCVA, f. 383, ap. 7, b. 214, 1. 30.

${ }^{151}$ Lietuvos užsienio reikalų ministro $1921 \mathrm{~m}$. gegužès $4 \mathrm{~d}$. laiškas Italijos aukštajam komisarui Konstantinopolyje. LCVA, f. 383, ap. 7, b. 214, 1. 31.

${ }^{152}$ Lietuvos užsienio reikalų ministro $1921 \mathrm{~m}$. gegužès 4 d. laiškas Didžiosios Britanijos aukštajam komisarui Konstantinopolyje. LCVA, f. 383, ap. 7, b. 214, 1. 32.
} 
$\mathrm{de}^{153}$, Bulgarijos užsienio reikalų ministrui ${ }^{154}$, Turkijos užsienio reikalų ministrui ${ }^{155}$. Tą pačią dieną buvo parašytas laiškas ir Lietuvos igaliotiniui tremtinių reikalams Konstantinopolyje kapitonui Broniui Blaveščiūnui. Jam pranešta apie vyr. ltn. J. Macevičiaus paskyrimą ir prašoma padèti vykdant instrukcijas ${ }^{156}$.

\subsection{Parengiamieji darbai Berlyne}

Lietuvos specialusis igaliotinis tremtiniams grąžinti Balkanų valstybėse vyr. ltn. Juozas Macevičius savo veiklą pradèjo Berlyne, laukdamas, kol Didžiosios Britanijos pasiuntinybe išduos vizą i Konstantinopolį ${ }^{157}$. Didžiosios Britanijos pasiuntinybė Berlyne vizos nedavè, todèl teko prašyti vizos Didžiosios Britanijos atstovo Kaune. Vyr. ltn. J. Macevičiaus pasas su britų viza (po paso siuntimo adresais Berlynas-Kaunas ir Kaunas-Berlynas) Berlyną pasiekè $1921 \mathrm{~m}$. gegužès $20 \mathrm{~d}$. Tą pačią dieną buvo gautos Čekoslovakijos ir Bulgarijos vizos ${ }^{158}$. Jugoslavija atsisake išduoti vizą, nes nežinojo, ar jos vyriausybẻ būtų pripažinusi vyr. ltn. Juozą Macevičių kaip igaliotinị tremtinių reikalams ${ }^{159}$. Jugoslavijos atstovybe Berlyne savo atsakyme pabrèžè, kad Jugoslavijos vyriausybei nebuvo iš anksto pranešta apie Lietuvos specialiojo igaliotinio paskyrimą ${ }^{160}$. Negavęs Jugoslavijos vizos, vyr. ltn. J. Macevičius planavo vykti per Vieną, tačiau vis tiek paprašè Lietuvos vyriausybès pranešti apie jo paskyrimą $\mathfrak{i}$

\footnotetext{
${ }^{153}$ Lietuvos užsienio reikalų ministro 1921 m. gegužès 4 d. laiškas Jugoslavijos URM Belgrade. LCVA, f. 383 , ap. 7, b. 214, 1. 33.

${ }^{154}$ Lietuvos užsienio reikalų ministro $1921 \mathrm{~m}$. gegužès 4 d. laiškas Bulgarijos URM. LCVA, f. 383, ap. 7, b. 214, 1. 34 .

${ }^{155}$ Lietuvos užsienio reikalų ministro $1921 \mathrm{~m}$. gegužès 4 d. laiškas Turkijos URM. LCVA, f. 383 , ap. 7, b. $214,1.35$.

15619210504 URM valdytojo, einančio ministro pareigas, laiškas kpt. B. Blaveščiūnui. LCVA, f. 383 , ap. 7, b. $214,1.38$.

15719210520 Lietuvos specialiojo igaliotinio tremtiniams grąžinti Balkanų valstybèse pranešimas URM PDD B. K. Balučiui. LCVA, f. 383, ap. 7, b. 214, 1. 15.

158 Ten pat.

159 Ten pat.

160 Ten pat.
} 
Belgradą ${ }^{161}$.

Berlyne vyr. ltn. J. Macevičius aiškinosi dèl karo pabėgèlių, tremtinių grižimo galimybių, bendravo su Tarptautinio Raudonojo Kryžiaus padalinio Berlyne vadovu. Latvijos ir Estijos igaliotiniams pavyko sudaryti su Tarptautiniu Raudonuoju Kryžiumi karo pabègèlių grąžinimo sutartis. Sutartyse buvo numatyta, kad vieno pabėgèlio grąžinimas, įskaitant kelionės išlaidas ir išlaikymą, kainuos 400 Vokietijos markių. Analogiškas pasiūlymas pateiktas ir Lietuvai per Lietuvos atstovą Latvijoje Dovą Zaunių, tačiau Lietuvos vyriausybė delsė atsakyti. Vyr. ltn. J. Macevičius siūlè apsvarstyti ši Tarptautinio Raudonojo Kryžiaus pasiūlymą, nes galimybių pigiau pargabenti pabėgèlius „vargu ar galima būtų surasti“162. Vyr. ltn. J. Macevičius prašè, net jei ir pasirašytų Lietuva sutartị su Tarptautiniu Raudonuoju Kryžiumi, neskubėti jos vykdyti, kol nesulauks tikslesnių žinių iš paskyrimo vietos ${ }^{163}$.

\subsection{Misija prasideda: Belgradas}

Vyr. ltn. J. Macevičius, 1921 m. birželio mèn. atvykęs ị Belgradą ir susipažinęs su kpt. L. Lippingo vedama konsulinès atstovybès apskaita, nustatè, kad igaliotinis Lietuvos Respublikai nèra skolingas. Nuo savo veiklos pradžios (gegužès 7 d.) iki specialiojo igaliotinio atvykimo (birželio $28 \mathrm{~d}$.) L. Lippingas buvo gavęs 6305 dinarus pajamų ir turejo 10817 dinarų išlai$\mathrm{dų}^{164}$. Susidariusį skirtumą kpt. L. Lippingas padengè savo lěšomis ${ }^{165}$. Todèl vyr. ltn. J. Macevičius pranešime URM siūlè atlyginti kpt. L. Lippingui raštinès išlaidas ir išmokèti algą nuo oficialios paskyrimo Lietuvos vyriausybès igaliotiniu Jugoslavijoje datos - $1921 \mathrm{~m}$. gegužès $7 \mathrm{~d} .{ }^{166}$ Atsiuntė ir konsulinio igaliotinio Belgrade etatų sąmatos projektą. Per mènesị igaliotiniui siūlè skirti 2700 dinarų (5400 auksinų), raštinès išlaidoms - 1300 dinarų

\footnotetext{
161 Ten pat.

162 Ten pat, 1. 16 .

163 Ten pat, 1. 17.

${ }^{164} 1922$ m. balandžio (pranešime data nenurodyta) V. Sidzikausko pranešimas URM apie misiją Turkijoje, Jugoslavijoje ir Bulgarijoje. LCVA, f. 383, ap. 7, b. 257, 1. 6.

${ }^{165} 19211104$ užsienio reikalų ministro laiškas Lietuvos atstovui Šveicarijoje V. Sidzikauskui. LCVA, f. 383, ap. 7, b. 257, 1. 41a.

166 Ten pat.
} 
(2600 auksinų). Minèjo ministerijai, kad Balkanuose galètų būti apie 200 lietuvių, norinčių grị̌žti ị Lietuvą, tačiau Jugoslavijoje jų būtų apie 60-70 ${ }^{167}$. Iki vyr. ltn. J. Macevičiaus atvykimo L. Lippingas (ir jo pirmtakas) buvo išdavęs apie 150 liudijimų. 15 liudijimų vèliau teko anuliuoti ${ }^{168}$. Paliko griežtas tolesnę veiklą, išduodant pasus, liudijimus ir vizas, reglamentuojančias instrukcijas. Vyr. ltn. J. Macevičius, ịvertinęs kpt. L. Lippingo veiklą Belgrade, neįžvelgè priežasčių, dèl kurių reikètų uždaryti konsulinę atstovybę, ir paliko jị toliau eiti Lietuvos vyriausybès igaliotinio Jugoslavijoje pareigas („su konsulinėmis teisėmis Lietuvos piliečių grąžinimo reikalui“169). Apie savo sprendimą vyr. ltn. J. Macevičius 1921 m. birželio 28 d. pranešè Jugoslavijos URM. Išvykdamas ị Konstantinopolị, jis išsivežè visą pasų archyvą ir finansinès apskaitos dokumentus ${ }^{170}$.

\subsection{Misija tęsiasi: Konstantinopolis}

Vyr. ltn. J. Macevičius, atvykęs ị Konstantinopolị, sužinojo, kad Lietuvos vyriausybès iggaliotinio biure vis dar dirba nelegalių dokumentų išdavimu ịtariamas J. Abramovičius ir jam talkinęs A. Lazarevas, ir šiuos du asmenis atstatydino ${ }^{171}$. Kpt. B. Blaveščiūnas specialiajam ígaliotiniui sudarè „doro ir atitinkamai jam pavestam darbui“ tinkamo žmogaus ịspūdị, todèl jo igaliojimų vyr. ltn. J. Macevičius neatšaukè ir paliko toliau eiti Lietuvos vyriausybès igaliotinio Turkijoje pareigas ${ }^{172}$.

Tuo metu, kai vyr. ltn. J. Macevičius tikrino Lietuvos igaliotinių Jugoslavijoje ir Turkijoje veiklą, Lietuvos užsienio reikalų ministerija $1921 \mathrm{~m}$. birželio $2 \mathrm{~d}$. gavo Steigiamojo Seimo nario Vinco Čepinskio prašymą sužinoti sūnaus karininko Vinco Čepinskio (Čepinskij) likimąą ${ }^{173}$. Ministras

\footnotetext{
167 Ten pat.

1681922 m. balandžio (pranešime data nenurodyta) V. Sidzikausko pranešimas URM apie misiją Turkijoje, Jugoslavijoje ir Bulgarijoje. LCVA, f. 383, ap. 7, b. 257, 1. 4.

169 Ten pat, 1. 5 .

170 Ten pat, 1. 4.

${ }^{171} 19211104$ užsienio reikalų ministro laiškas Lietuvos atstovui Šveicarijoje V. Sidzikauskui. LCVA, f. 383, ap. 7, b. 257, 1. 41.

172 Ten pat.

17319210602 Steigiamojo Seimo nario V. Čepinskio prašymas URM. LCVA, f. 383, ap. 7, b. $214,1.11$.
} 
Juozas Purickis išsiuntė telegramą ị Konstantinopolị kpt. B. Blaveščiūnui, prašydamas išsiaiškinti, ar yra Turkijoje belaisvių iš Krymo. Iš $1921 \mathrm{~m}$. birželio $28 \mathrm{~d}$. Lietuvos igaliotinio sekretoriaus P. Oželio rašyto laiško URM sužinojo, kad karininkas Vincas Čepinskis (Čepinskij) „lietuvių tremtinių sąrašuose neužregistruotas“. Informacijos apie V. Čepinskị P. Oželis teiravosi gen. ltn. P. Vrangelio štabe, kur jam buvo paaiškinta, kad „belaisviai iš Krymo išvežti nebuvo“, ir prašè Sovietų Rusijos prekybos igaliotinio Konstantinopolyje Kudišo (vardas autorei nežinomas) pagalbos. Pastarasis pažadejjo susisiekti su „Krymo valdžios pirmininku“. P. Oželis prašè patikslinti V. Čepinskio patekimo į nelaisvę detales ir pažadejo pranešti, jei gautų kokios informacijos ${ }^{174}$.

Peržvelgęs igaliotinio finansinę apskaitą vyr. ltn. J. Macevičius įsitikino, kad yra 35475 auksinų trūkumas ${ }^{175}$. Vyr. ltn. J. Macevičius padengè dalị kpt. B. Blaveščiūno skolų, tačiau visai trūkstamai sumai padengti pritrūko pinigų. Dalị turètų pinigų davė skurstantiems lietuviams tremtiniams (kariškiams). Už biuro patalpų nuomą igaliotinis taip pat buvo skolingas, ir patalpų šeimininkas (Čekoslovakijos pilietis) ketino jam kelti bylą ${ }^{176}$. Igaliotinio raštinès ịplaukų užtekdavo tik raštinės personalui pragyventi ${ }^{177} .1921 \mathrm{~m}$. liepos $16 \mathrm{~d}$. vyr. ltn. J. Macevičius paprašè URM atsiųsti avansą konsulinès atstovybès skoloms padengti ir tremtinių reevakuacijai vykdyti ${ }^{178}$. Atsižvelgdamas i vietos sąlygas vyr. ltn. J. Macevičius sudarè ir URM išsiuntė vieno mènesio igaliotinio biuro etatų sąmatos, kurią sudarè 23650 auksinų, projektą (išsamiau žr. 3 lentelèje).

\footnotetext{
${ }^{174} 19210628$ P. Aželio, Lietuvos vyriausybès igaliotinio Turkijoje, sekretoriaus laiškas URM. LCVA, f. 383, ap. 7, b. 214, 1. 8.

${ }^{175} 19211104$ užsienio reikalų ministro laiškas Lietuvos atstovui Šveicarijoje V. Sidzikauskui. LCVA, f. 383, ap. 7, b. 257, 1. 41.

${ }^{176} 19210827$ J. Macevičiaus pranešimas užsienio reikalų ministrui. LCVA, f. 383, ap. 7, b. $257,1.43-43 a, 44$.

177 Ten pat, 1. 43-43a.

178 Ten pat, 1. 44a-45.
} 
3 lentelè. Vyr. ltn. J. Macevičiaus sudarytas Lietuvos vyriausybės igaliotinio biuro etatų sąmatos (1 mènesio) projektas

\begin{tabular}{|l|c|c|}
\hline \multicolumn{1}{|c|}{ Lèšų paskirtis } & Suma Turkijos liromis & Suma auksinais \\
\hline Igaliotinio alga & 150 & 8250 \\
\hline Igaliotinio sekretoriaus alga & 100 & 5500 \\
\hline Igaliotinio raštinès darbuotojo alga & 60 & 3300 \\
\hline Tarno alga & 40 & 2200 \\
\hline Igaliotinio būstinès / biuro išlaidos & 80 & 4400 \\
\hline \multicolumn{1}{|r|}{ Iš viso: } & $\mathbf{4 3 0}$ & $\mathbf{2 3 6 5 0}$ \\
\hline
\end{tabular}

Sudaryta autorès remiantis: $1922 \mathrm{~m}$. balandžio (pranešime data nenurodyta) V. Sidzikausko pranešimas URM apie misiją Turkijoje, Jugoslavijoje ir Bulgarijoje. LCVA, f. 383, ap. 7, b. 257, 1. 12 .

Užsienio reikalų ministras J. Purickis, gavęs vyr. ltn. J. Macevičiaus pranešimus, $1921 \mathrm{~m}$. rugpjūčio $19 \mathrm{~d}$. telegramoje pareikalavo, kad kpt. B. Blaveščiūnas atvyktų i Kauną su visu jo biuro išduotų pasų sąrašu ${ }^{179}$. Vyr. ltn. J. Macevičius buvo labai nustebintas tokio telegramos turinio ir rugpjūčio $27 \mathrm{~d}$. parašè ilgą ir išsamų pranešimą ministrui. Jame išdèstė argumentus, kodèl nevertètų kviestis kpt. B. Blaveščiūno ị Kauną. Pirma, tai Lietuvos biudžetui kainuos 20-30 tūkstančių auksinų ir problemos neišspręs ${ }^{180}$. Antra, nesumokejęs už biuro nuomą patalpų savininkui (liko skolingas 350 Turkijos lirų), B. Blaveščiūnas išvykti negali, nes savininkas jo neišleis. Trečia, B. Blaveščiūnas yra skolingas ir privatiems asmenims, kurie jam, negrąžinusiam skolų, išvykti iš Konstantinopolio neleis. Ketvirta, nèra iš kur paimti pinigų kelionei ${ }^{181}$.

Vyr. ltn. J. Macevičius siūlè ministerijai nuspręsti, kokiam tikslui Lietuvai reikalinga konsulinè atstovybė Turkijoje - ar tarptautinès prekybos plètotei, ar tremtinių Lietuvos piliečių teisėms apginti. Pirmuoju atveju siūlè ịkurti nuolatinę konsulinę atstovybę, antruoju - pratęsti jau esančios veiklą, iki bus repatrijuoti visi lietuviai pabėgèliai, atvykę i Turkiją su

${ }^{179} 19210819$ užsienio reikalų ministro J. Purickio telegrama į Konstantinopolị J. Macevičiui. LCVA, f. 383 , ap. 7, b. 214, 1. 9.

${ }^{180} 19210827$ J. Macevičiaus pranešimas užsienio reikalų ministrui. LCVA, f. 383, ap. 7, b. $257,1.44 \mathrm{a}$.

181 Ten pat, 1. 43a. 
gen. ltn. P. Vrangelio armijos likučiais ${ }^{182}$. Galiausiai vyr. ltn. J. Macevičius paklausė ministerijos, ką daryti su konsuline atstovybe Turkijoje: ją uždaryti ar palikti, pavedus savo pareigas sekretoriui P. Oželiui. Uždaryti ministrui nepatarè, nes tada negalètų grị̌ti Konstantinopolyje tebesantys lietuviai tremtiniai, t. y. „atsilieptų neužbaigtam reikalui “183.

Specialusis igaliotinis paprašè URM atsiųsti pinigų (nurodžius, ị kurị banką siųsta) kpt. B. Blaveščiūno skoloms sumokèti, pabėgèliams grąžinti ir jam pačiam, nes jis, negalèdamas sumokèti už viešbutị, negali išvykti ì paskyrimo vietą Vatikane ${ }^{184}$. Pinigai vyr. ltn. J. Macevičių pasiekė tik $1921 \mathrm{~m}$. rugsejjo pradžioje. $1921 \mathrm{~m}$. rugsèjo 6 d. viceministras Petras Klimas telegrama ị Konstantinopoli pranešè, kad per „Deutsche Bank“ Berlyne yra pervesta 50000 markių lietuviams tremtiniams iš Balkanų šalių sugrąžinti, ir paprašè informuoti apie pinigų gavimą ministerijos nustatyta tvarka ${ }^{185}$.

\subsection{Misijos rezultatai}

J. Purickis, išanalizavęs visą vyr. ltn. J. Macevičiaus atsiųstą informaciją, 1921 m. lapkričio 4 d. laiške V. Sidzikauskui svarstė keletą variantų. Pirmasis - uždaryti jau veikiančias konsulines atstovybes Konstantinopolyje ir Belgrade ir kooperuotis su Latvija ir Estija paskiriant vieną konsulini igaliotinį. Antrasis - laikinai paskirti vieną igaliotinị visoms Balkanų šalims „be raštinès“ (ministro manymu, pasirūpinti tremtinių reikalais galima ir gyvenant viešbutyje ${ }^{186}$. Svarstė kpt. B. Blaveščiūno ir jo sekretoriaus P. Oželio kandidatūras ${ }^{187}$. Galiausiai nusprende pasiųsti Lietuvos atstovą Šveicarijoje V. Sidzikauską, suteikus specialius igaliojimus sutvarkyti finansinius reikalus ir uždaryti konsulines atstovybes.

\footnotetext{
182 Ten pat, 1. 44a.

183 Ten pat, 1. 43-43a.

184 Ten pat, 1. 43-43a.

${ }^{185} 19210906$ P. Klimo telegrama J. Macevičiui ị Konstantinopolị. LCVA, f. 383, ap. 7, b. $214,1.4$.

${ }^{186} 19211104$ užsienio reikalų ministro laiškas Lietuvos atstovui Šveicarijoje V. Sidzikauskui. LCVA, f. 383, ap. 7, b. 257, 1. 41a.

187 Ten pat, 1. 42-42a.
} 
Apibendrinant vyr. ltn. J. Macevičiaus penkis mėnesius (1921 m. gegužès-rugsèjo mėn.) trukusios misijos Jugoslavijoje ir Turkijoje rezultatus galima teigti, kad jis vykde instrukcijoje nurodytas funkcijas - atleido iš pareigų Lietuvos konsulineje atstovybëje Turkijoje dirbusius susikompromitavusius asmenis ir patvirtino kpt. B. Blaveščiūno paskirtą kpt. L. Lippingą Lietuvos vyriausybès igaliotiniu Belgrade, atliko pasų ir vizų išdavimo apskaitą, ịvertinęs tarnautojų finansinę padètí, parengè ir ministerijai persiuntė Lietuvos konsulinių atstovybių Konstantinopolyje ir Belgrade etatų sąmatą, sušelpè pabėgèlius ir sumokejo dalį Lietuvos vyriausybės iggaliotinio Turkijoje skolų už biuro nuomą ir pabėgèlių išlaikymą bendrabutyje.

\section{VACLOVO SIDZIKAUSKO MISIJA. KONSULINIŲ ATSTOVYBIŲ UŽDARYMAS}

\subsection{Ministro ir Politikos departamento direktoriaus instrukcijos V. Sidzikauskui}

1921 m. lapkričio 4 d. užsienio reikalų ministras parašè V. Sidzikauskui ilgą ir išsamų laišką, kuriame aprašè susidariusią Lietuvos konsulinio atstovavimo padètị Turkijoje, Jugoslavijoje ir Bulgarijoje ${ }^{188}$. Ypatingą dèmesį ministras laiške Lietuvos atstovui skyrẻ Konstantinopolyje, Belgrade ir Sofijoje veikiančių komitetų narių, iggaliotinių, jų biurų (raštinių) darbuotojų (buvusių ir esamų) ir jų veiklos charakteristikai, finansinei situacijai. Aptarta vyr. ltn. J. Macevičiaus misija Konstantinopolyje ir Belgrade ir jos rezultatai (priimti sprendimai, etatų sąmatų siūlymai, skolos). Atkreiptas demesys i vyr. ltn. J. Macevičiaus surinktus faktus, kuriuos reikia patikrinti, pabrèžta, kad jokiu būdu negalima ịsileisti asmenų, kilusių iš Lenkijos okupuoto Vilniaus krašto, nes neįmanoma patikrinti jų kilmès dokumentų, o reikiamus dokumentus jiems gali išduoti tik Lenkijos atstovas, ir rusų valdininkų, dvasininkų, mokytojų (kurie buvo atsiųsti dèl

188 Ten pat, 1. 38-45. 
rusifikacijos ${ }^{189}$. Ministras buvo nepatenkintas tuo, kad vyr. ltn. J. Macevičius ne tik paliko toliau dirbti kpt. L. Lippingą, bet ir pratęsė jo igaliojimus. Ministras V. Sidzikausko primygtinai prašè išsiaiškinti, kiek dar yra Balkanų šalyse likusių Lietuvos piliečių ir kokiu pagrindu jiems išduodami pasai. Neteisètai išduotus pasus prašè anuliuoti ${ }^{190}$, taip pat ìsigilinti ị konsulinių atstovybių finansinę situaciją ir kritiškai įvertinti vyr. ltn. J. Macevičiaus pateiktus etatų sąmatų projektus ${ }^{191}$.

1921 m. lapkričio 17 d. detalesnę instrukciją V. Sidzikauskui ị Berną atsiuntė URM tuo metu viceministrą P. Klimą pavadavęs Politikos departamento direktorius B. K. Balutis. Kaip ir ministras, B. K. Balutis primygtinai reikalavo anuliuoti neteisètai ne Lietuvos piliečiams išduotus pasus, kad vèliau Antantès valstybès nepareikalautų Lietuvos vyriausybės atlyginti už jų išlaikymą ir repatriaciją. Po vyr. ltn. J. Macevičiaus vizito kpt. B. Blaveščiūno išduoti pasai buvo laikomi oficialiais Lietuvos pilietybės įrodymais „su visomis iš to išplaukiančiomis pasekmėmis“192. B. K. Balutis paprašė V. Sidzikausko atlikti griežtą visų išduotų pasų kontrolę, apie ne Lietuvos piliečiams (ar abejotinos kilmès asmenims) išduotus pasus, sudarius jų sąrašą, pranešti Antantès šalių aukštiesiems komisarams Konstantinopolyje ir priimančiųjų šalių vyriausybėms. Siunčiamajame rašte paaiškinti, kad dokumentai išduoti neteisètai „dèl atitinkamų instrukcijų stokos" arba kad jų pilietybei ịrodyti stinga reikiamų dokumentų, todèl Lietuvos vyriausybè negali imtis atsakomybės už šiuos asmenis, kol jų pilietybè iki galo nepaaiškès. Instrukcijoje pakartotas prašymas neišduoti pasų iš „Vidurio Lietuvos“"193 kilusiems asmenims, nebent dèl jų lietuviškos kilmès nekiltų abejonių (,išskyrus neabejotiniems lietuviams“) ${ }^{194}$.

\footnotetext{
189 Ten pat, 1. 41a.

190 Ten pat, 1. 42 .

191 Ten pat, 1. 42a.

19219211117 URM viceministro laiškas Lietuvos atstovui Šveicarijoje V. Sidzikauskui. LCVA, f. 383, ap. 7, b. 257, 1. 34-35.

${ }^{193}$ Vidurio Lietuva - teritorinis darinys, apėmęs Vilniaus krašto dalị ir dalị vakarinès Baltarusijos, atsiradęs L. Želigovskiui užèmus Vilniaus kraštą. Egzistavo nuo 1920 m. spalio 9 iki 1922 m. kovo 24 d.

${ }^{194} 19211117$ URM viceministro laiškas Lietuvos atstovui Šveicarijoje V. Sidzikauskui. LCVA, f. 383, ap. 7, b. 257, 1. 34-35.
} 


\subsection{Lietuvos vyriausybės igaliotinio Belgrade kpt. L. Lippingo atšaukimas}

I Belgradą V. Sidzikauskas atvyko $1922 \mathrm{~m}$. kovo 12 d. Susipažino su Lietuvos vyriausybès igaliotinio Jugoslavijoje kpt. L. Lippingo veikla ir tvarkoma dokumentacija. Nuo vyr. ltn. J. Macevičiaus iki V. Sidzikausko misijos L. Lippingas buvo išdavęs 41 pasą. Patikrinus paaiškejjo, kad tik 14 asmenu turèjo teisę tokị pasą gauti. Nuo $1921 \mathrm{~m}$. birželio 28 iki $1922 \mathrm{~m}$. kovo $16 \mathrm{~d}$. igaliotinis gavo 6850 dinarų pajamų, o išleido 8361 dinarą. Pateikè visus išlaidas pateisinančius dokumentus. L. Lippingas skundèsi V. Sidzikauskui, kad jis taip ir nesulaukęs vyr. ltn. J. Macevičiaus žadètų kreditu igaliotinio veiklai finansuoti, dèl to teko „pravalgyti savo žmonos karakulio kailinius“. Pareiškè norą gauti 2500 dinarų algos už kiekvieną darbo mènesị (bendra suma - 22500 dinarų). V. Sidzikauskas, susipažinęs su finansine apskaita, nusprendè padengti igaliotinio raštinès išlaidas (770 dinarų), pašto išlaidas (291 dinarą), sumokèti už skelbimus laikraščiuose dèl Lietuvos piliečiu reikalu (100 dinarų) ir raštinès kambario nuomą (7200 dinarų), taip susidare 8361 dinaras išlaidų, prieš tai iš tos sumos atėmus gautas pajamas (6580 dinarų). Taigi išvykdamas V. Sidzikauskas išmokejo L. Lippingui 3011 dinarų (t. y. 402 Prancūzijos frankus) ir papraše URM patvirtinti šią išlaidų sumą ${ }^{195}$.

Sužinota, kad Jugoslavijoje lietuvių likę vos keletas ir jie neplanuoja artimiausiu metu grįžti i Lietuvą ${ }^{196}$. Nebelikus Jugoslavijoje i t tévynę norinčiu grịžti lietuvių, igaliotinis piliečių grąžinimo reikalams tapo nebereikalingas. V. Sidzikausko manymu, apie Lietuvos atstovybę Belgrade, kol Jugoslavija nepripažino Lietuvos de jure, galvoti buvo per anksti, todèl, padèkojęs Lietuvos Respublikos vyriausybès vardu už „pasidarbavimą lietuvių tremtinių, belaisvių ir atbègèlių naudai“, atleido kpt. L. Lippingą iš igaliotinio pareigu $1922 \mathrm{~m}$. kovo $16 \mathrm{~d} .{ }^{197}$, o kovo $17 \mathrm{~d}$. apie tai pranešè Jugoslavijos

\footnotetext{
1951922 m. balandžio (pranešime data nenurodyta) V. Sidzikausko pranešimas URM apie misiją Turkijoje, Jugoslavijoje ir Bulgarijoje. LCVA, f. 383, ap. 7, b. 257, 1. 6.

196 Ten pat, 1. 3-4.

197 „Vyriausybės suteikta man galia aš Tamstą paleidžiu su šia diena nuo p. Blaveščiūno LR vyriausybès delegato Konstantinopolyje ir p. Macevičiaus, specialaus igaliotinio tremtinių grąžinimui Balkanų valstybėse pavestųjų Tamstai pareigų èjimo.“ Žr.: 19220316 V. Sidzikausko raštas Lietuvos vyriausybès igaliotiniui Serbų, Kroatų ir Slovėnų valstybėse Belgrade Leonidui Lippingui. LCVA, f. 383, ap. 7, b. 257, 1. 14a.
} 
užsienio reikalų ministerijai (URM Momčilo Ninčičiui ${ }^{198}$ ). Tuo pačiu raštu (kovo 16 d.) buvo nutraukta ir plk. A. Benjaševičiaus įsteigtos Lietuvos Respublikos piliečių tarybos, taip pat „biuro lietuviams tremtiniams, karo belaisviams ir atbėgèliams grąžinti“" veikla. $1921 \mathrm{~m}$. spalio mèn. URM vykusiame Lietuvos pasiuntinių pasitarime buvo nutarta, kad Lietuvos atstovas Italijoje bus atstovas ir Balkanų valstybėse, tačiau V. Sidzikauskas nusprendè, kad dèl tuo metu vykusio Italijos kivirčo su Jugoslavija būtų politiškai korektiškiau, jei Lietuvos piliečiais Balkanų šalyse rūpinsis atstovas Šveicarijoje. Kitas motyvas - jis jau buvo susipažinęs su situacija ${ }^{199}$.

\subsection{Lietuvių komitetas Sofijoje ( $1921 \mathrm{~m}$. birželis- 1922 m. kovo 21 d.)}

Nuo $1921 \mathrm{~m}$. birželio veikè Lietuvių komitetas Sofijoje (Bulgarijoje), jam vadovavo Gudu vyriausybès igaliotinis gen. mjr. Aleksandras Golubincevas ${ }^{200}$. Gen. mjr. A. Golubincevas i Bulgariją buvo paskirtas plk. Ivano Jermačenkos (nuo $1921 \mathrm{~m}$. Gudų Liaudies Respublikos atstovo Konstantinopolyje ir generalinio konsulo Balkanų šalyse, kuris ịsteigé konsulines atstovybes Jugoslavijoje ir Bulgarijoje). Komiteto nariais buvo paskirti J. Abramovičius ir Krasauskis (vardas autorei nežinomas; pastarasis Sofijoje tuo metu jau nebegyveno). J. Abramovičius jau turëjo komitetų kūrimo patirties - buvo „Krymo lietuvių komiteto nariu ir pirmininku“. Tačiau, nebūdamas tikras, ar gaus Bulgarijos vyriausybès pritarimą savo veiklai, nusprendè apsidrausti ir komiteto pirmininku pasiūlè tapti gen. mjr. A. Golubincevui, kuris tuo metu buvo oficialus Gudų Liaudies Respublikos vyriausybès igaliotinis, pripažintas Bulgarijos vyriausybès. Generolas sutiko būti pirmininku ir pranešè apie tai Lietuvos vyriausybei, tačiau pritarimo nesulaukè. Todèl nei pasų, nei vizų negalèjo išduoti, bet tarpininkavo lietuviams, persiųsdamas jų prašymus kpt. B. Blaveščiūnui ir kpt. L. Lippingui ${ }^{201}$. I Sofiją $1922 \mathrm{~m}$. kovo 19 d. atvykusiam V. Sidzikauskui gen. mjr. A. Golubincevas perdavè tik kelis lietuvių, gyvenančių

\footnotetext{
19819220317 V. Sidzikausko nota Jugoslavijos URM. LCVA, f. 383, ap. 7, b. 257, 1. 15-16. $1991922 \mathrm{~m}$. balandžio (pranešime data nenurodyta) V. Sidzikausko pranešimas URM apie misiją Turkijoje, Jugoslavijoje ir Bulgarijoje. LCVA, f. 383, ap. 7, b. 257, 1. 5.

200 Ten pat, 1. 7-9.

201 Ten pat.
} 
Bulgarijoje, prašymus ${ }^{202}$.

Lietuvių komiteto Sofijoje pirmininkas skundèsi Lietuvos atstovui, kad Vokietijos konsulas Sofijoje nebevizuoja jo išduotų Gudų Liaudies Respublikos pasų. V. Sidzikauskas gen. mjr. A. Golubincevui pareiškè, kad neturi igaliojimų vizuoti ị Lietuvą vykstančių gudų pasų. Be to, V. Sidzikauskas nurodè, kad „su jo išduotais pasais ir vizomis ị Baltarusiją grị̌ti nebegalima“, todèl turès apie tai pranešti Lietuvos, o pastaroji „Gudų vyriausybei“203. Generolas teisinosi, kad veikia vadovaudamasis plk. I. Jermačenkos instrukcijomis. Iš tiesų jo išduotų pasų labiausiai reikejjo gen. ltn. P. Vrangelio armijos karininkams, kurių su rusiškais pasais neileisdavo ì Čekoslovakiją ir Austriją ${ }^{204}$.

$1921 \mathrm{~m}$. kovo $21 \mathrm{~d}$. V. Sidzikauskas Bulgarijos ministrui pirmininkui Aleksandarui Stamboliyskiui nusiuntė notą, kurioje nurodè, kad Lietuvių komitetas Sofijoje, vadovaujamas gen. mjr. A. Golubincevo (nariai J. Abramovičius ir Krasauskis), neturi „Lietuvos vyriausybės patvirtinimo atstovauti Lietuvos Respublikai Bulgarijoje ir neturi teisès išduoti dokumentų lietuviams, grịžtantiems ị tèvynę", kad „Lietuvos diplomatinị ir konsulinį atstovavimą Bulgarijoje perima Lietuvos atstovybė Šveica-

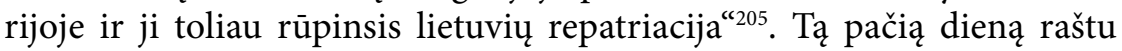
gen. mjr. A. Golubincevui pranešta, kad Lietuvių komitetas Sofijoje „Lietuvos vyriausybès yra laikomas privatine organizacija, kuriai vyriausybé nèra suteikusi jokių oficialių ir neoficialių funkcijų“ ir kad „komitetas ne tik neturi teisès atstovauti Bulgarijoje Lietuvos Respublikos vyriausybei, bet ir negali išdavinèti pasų Lietuvos piliečiams arba vizų norintiems grịžti ar važiuoti Lietuvon“. V. Sidzikauskas padèkojo generolui už „pasidarbavimą lietuvių tremtinių, belaisvių ir atbėgėlių naudai“ ${ }^{206}$.

\footnotetext{
202 Ten pat.

203 Ten pat.

204 Ten pat.

${ }^{205} 19220321$ V. Sidzikausko nota Bulgarijos ministrui pirmininkui A. Stambolyiskiui. LCVA, f. 383, ap. 7, b. 257, 1. 14.

${ }^{206} 19220321$ V. Sidzikausko nota Lietuvių komiteto Sofijoje pirmininkui gen. Golubincevui. LCVA, f. 383, ap. 7, b. 257, 1. 17.
} 


\section{3. „Konstantinopolio epopėjos“ pabaiga}

V. Sidzikauskas ị Konstantinopoli atvyko kovo $24 \mathrm{~d}{ }^{207}$ Pirmiausia pasirūpino pasų archyvu ir ne Lietuvos piliečiams išduotų pasų anuliavimu. Nuo 1921 m. vasario 28 iki 1922 m. kovo 31 d. buvo išduoti 197 Lietuvos pasai. Abejonių nekèlé tik 110 pasų savininkų pilietybė. 27 pasus jau buvo anuliavęs pats kpt. B. Blaveščiūnas. Dẻl kitų 28 pasų anuliavimo notą Antantès šalių aukštiesiems komisarams ir $1922 \mathrm{~m}$. kovo $28 \mathrm{~d}$. notą Bulgarijos vyriausybei ${ }^{208}$ pasiuntė V. Sidzikauskas, prašydamas atimti Lietuvos Respublikos pasus iš A. Millerio ir J. Abramovičiaus ir atsiųsti juos Lietuvos atstovybei Šveicarijoje ${ }^{209}$. V. Sidzikauskas, pasikalbejjęs su kpt. B. Blaveščiūnu, ịsitikino, kad lietuvių, norinčių grịžti ị tèvynę, Turkijoje neliko, todèl V. Sidzikauskas nuo $1922 \mathrm{~m}$. kovo $31 \mathrm{~d}$. atleido kpt. B. Blaveščiūną iš Lietuvos vyriausybès igaliotinio Turkijoje pareigų ir uždarẻ konsulinę atstovybę. Kovo 30 d. rašte kpt. B. Blaveščiūnui V. Sidzikauskas padèkojo už dvejų metų darbą Turkijoje ir patikino turịs „vilties, kad ir sugrị̌žs Lietuvon Tamsta tokiu pat pasišventimu naudosi savo jègas ir savo patyrimą mūsų atgimusios valstybès gerovei“"210. Apie savo sprendimus atleisti konsulinị igaliotinị ir uždaryti biurą, kuris rūpinosi lietuvių pabègèlių grąžinimo reikalais, $1922 \mathrm{~m}$. kovo $30 \mathrm{~d}$. pranešè Antantès šalių aukštiesiems komisarams Konstantinopolyje. Notoje padèkojo už pagalbą Lietuvos vyriausybės igaliotiniui ir informavo, kad Lietuvos piliečių globą Turkijoje („,visoje Atamano imperijoje“) perèmé Lietuvos atstovybé Šveicarijoje ${ }^{211}$.

\footnotetext{
${ }^{207}$ Sidzikauskas V. Lietuvos diplomatijos parašteje. Vilnius: Vaga, 1994, p. 44; 1922 m. balandžio (pranešime data nenurodyta) V. Sidzikausko pranešimas URM apie misiją Turkijoje, Jugoslavijoje ir Bulgarijoje. LCVA, f. 383, ap. 7, b. 257, 1. 9.

${ }^{208} 19220328$ V. Sidzikausko nota URM Sofijoje. LCVA, f. 383, ap. 7, b. 257, 1. 18.

${ }^{209}$ Sidzikauskas V. Lietuvos diplomatijos parašteje. Vilnius: Vaga, 1994, p. 44; 1922 m. balandžio (pranešime data nenurodyta) V. Sidzikausko pranešimas URM apie misiją Turkijoje, Jugoslavijoje ir Bulgarijoje. LCVA, f. 383, ap. 7, b. 257, 1. 11-13.

${ }^{210} 19220330$ V. Sidzikausko raštas B. Blaveščiūnui, Lietuvos vyriausybès igaliotiniui Turkijoje. LCVA, f. 383, ap. 7, b. 257, 1. 19.

${ }^{211} 19220330$ V. Sidzikausko nota Antantès aukštiesiems komisarams (Italijos, Prancūzijos - gen. Pellé, Didžiosios Britanijos - Bertui Rumboldtui). LCVA, f. 383, ap. 7, b. 257, 1. 22-23.
} 
Ataskaitoje apie konsulinių atstovybių Balkanų šalyse ir Turkijoje uždarymą V. Sidzikauskas ministeriją informavo apie Konstantinopolyje veikiantị Gudų Liaudies Respublikos generalinị konsulatą, jame dirbantị generalinị konsulą plk. I. Jermačenką (orig. Jermačenko) ir jo sekretorių Avčinnikovą (vardas autorei nežinomas). Iš Gudų Liaudies Respublikos vyriausybès jie algų negaudavo, gyveno tik iš už išduotus pasus ir vizas gautų pajamų. V. Sidzikauskas atkreipé ministerijos dèmesị i š ši konsulatą neatsitiktinai, nes plk. I. Jermačenka buvo vizavęs pasus ił Lietuvą vykstantiems „naudingiems žmonėms“. Paklaustas, kodèl taip elgiasi, jis pareiškè, kad „esanti padaryta sutartis su mūsų Vyriausybe, kuria einant tūlas gudų skaičius gali ịvažiuoti Lietuvon“212. V. Sidzikauskas siūlè ministerijai imtis žygių, kad Baltarusijos konsulinès atstovybès Balkanų šalyse ir Turkijoje būtų uždarytos ${ }^{213}$.

V. Sidzikauskas baigė mokèti Lietuvos vyriausybès igaliotinio skolas (žr. 4 lentelę): už bendrabutị, kuriame gyveno lietuvių tremtiniai, belaisviai ir pabėgèliai, igaliotinio kambario ir igaliotinio biuro nuomą - 465,5 Turkijos liros, konsulinès atstovybės tarnautojų algoms ir kelionei ị Lietuvą - 260,5 Turkijos liros (žr. 4 lentelę). Liko nesumokèta 100 Turkijos lirų skola Raudonojo Kryžiaus atstovui. Ministerijai siūlè ị Lietuvą grị̌zusiems konsulinès atstovybės tarnautojams „pradèti gyvenimui Lietuvoje“ išduoti: B. Blaveščiūnui - 10 000-15 000 auksinų, P. Oželiui - 5000 auksinų, o Chanovui (vardas autorei nežinomas) - 3000 auksinų ${ }^{214}$.

\footnotetext{
${ }^{212}$ Plk. I. Jermačenka greičiausiai turèjo omenyje Lietuvos ir Baltarusijos (tiksliau - Gudu Liaudies Respublikos vyriausybès, vad. V. Lastauskio) 1920 m. lapkričio $11 \mathrm{~d}$. pasirašytą susitarimą, kurio ketvirtasis paragrafas (juo abi vyriausybės įsipareigojo palaikyti viena kitą užsienyje) dèl atstovavimo Balkanų šalyse ir Turkijoje galejo būti ígyvendintas praktiškai. Žr.: Gimžauskas E. Baltarusiu veiksnys formuojantis Lietuvos valstybei 1915-1923 m. Vilnius: LLI leidykla, 2003, p. 126-137.

${ }^{213} 1922 \mathrm{~m}$. balandžio (pranešime data nenurodyta) V. Sidzikausko pranešimas URM apie misiją Turkijoje, Jugoslavijoje ir Bulgarijoje. LCVA, f. 383, ap. 7, b. 257, 1. 11-13.

214 Ten pat.
} 
4 lentelè. 1922 m. kovo mèn. V. Sidzikausko išmokètos Lietuvos vyriausybès igaliotinio Turkijoje skolos

\begin{tabular}{|l|c|c|}
\hline \multicolumn{1}{|c|}{ Paskirtis } & $\begin{array}{c}\text { Skolos suma } \\
\text { Turkijos } \\
\text { liromis }\end{array}$ & Pastabos \\
\hline $\begin{array}{l}\text { Už bendrabutį, kur gyveno lietuviai } \\
\text { tremtiniai, belaisviai ir pabègèliai }\end{array}$ & 175 & $\begin{array}{c}50 \text { lirų iš tos sumos turèjo } \\
\text { grąžinti Gudų vyriausybe் }\end{array}$ \\
\hline $\begin{array}{l}\text { Už igaliotinio nuomojamą kambari } \\
\text { Novotnui }\end{array}$ & 200 & \\
\hline Už igaliotinio biuro nuomą Kislauskiui & 90,5 & \\
\hline $\begin{array}{l}\text { B. Blaveščiūno kelionei i Lietuvą ir jo } \\
\text { užstatytiems daiktams išpirkti }\end{array}$ & 117 & \\
\hline Alga sekretoriui P. Oželiui & 73,5 & \\
\hline Alga raštinès tarnautojui Chanovui & 70 & \\
\hline \multicolumn{1}{|c|}{ Iš viso: } & 726 & \\
\hline
\end{tabular}

Sudaryta autorès remiantis: $1922 \mathrm{~m}$. balandžio (pranešime data nenurodyta) V. Sidzikausko pranešimas URM apie misiją Turkijoje, Jugoslavijoje ir Bulgarijoje. LCVA, f. 383, ap. 7 , b. $257,1.12$.

Ataskaitoje Užsienio reikalų ministerijai V. Sidzikauskas teigiamai įvertino kpt. B. Blaveščiūną, jo, kaip aviatoriaus, gabumus, veiklą Krymo lietuvių komitete, atsisakymą stoti ị gen. ltn. P. Vrangelio armiją. Pabrèžè, kad „buvo atliktas ir gan svarbus ir valstybei naudingas darbas. Daugelis lietuvių buvo prievarta sumobilizuoti i Denikino ir Vrangelio armiją. Su rusų kariuomene jie buvo atvežti Turkijon ir čia atsidūrẻ be galo sunkioj padèty“. Jo manymu, „Blaveščiūno sukurtas Komitetas ir vèliau, būdamas igaliotiniu, jis dejo visas pastangas, kad lietuvius išlaisvinus ir kad davus jiems galimybès sugrižti tèvynèn“. Pavadino jị jaunu, gabiu ir „nuoširdžiu lietuviu patriotu“ ir „prašè ministeriją padèti jam rasti Lietuvoje tarnybą “215. Tuo, kaip teigè pats V. Sidzikauskas ataskaitoje URM, „Konstantinopolio epopèja gali būti baigta“216.

${ }^{215}$ Nuo 1922 m. gegužès 1 d. kpt. B. Blaveščiūnas buvo paskirtas URM Europos centro sekretoriumi, 1922 m. rugsėjo 1 d. - URM ypatingų reikalų valdininku. $1930 \mathrm{~m}$. vasario 1 d. B. Blaveščiūnas tapo Lietuvos pasiuntinybès Paryžiuje Konsulinio skyriaus vedèju. Žr. URM žinynas. Kaunas, 1933, p. 232.

${ }^{216} 1922 \mathrm{~m}$. balandžio (pranešime data nenurodyta) V. Sidzikausko pranešimas URM apie misiją Turkijoje, Jugoslavijoje ir Bulgarijoje. LCVA, f. 383, ap. 7, b. 257, 1. 11-13. 
Apibendrinant galima teigti, kad V. Sidzikauskas misijos metu (1922 m. kovo 12-31 d.) operatyviai išsprendè visas dèl Lietuvos konsulinio atstovavimo Turkijoje, Jugoslavijoje ir Bulgarijoje susidariusias problemas: pirma, anuliavo ne Lietuvos piliečiams išduotus pasus; antra, padèkojęs už rūpestị grąžinant Lietuvos piliečius ị tėvynę, atšaukẻ Lietuvos vyriausybės igaliotinius Konstantinopolyje ir Belgrade ir uždraudè gen. mjr. A. Golubincevui vykdyti bet kokias su Lietuvos piliečių atstovavimu susijusias funkcijas, o Lietuvos piliečių globą tose šalyse perdavẻ Lietuvos atstovybei Šveicarijoje; trečia, ł̇vykdè Lietuvos vyriausybès igaliotinių prisiimtus finansinius ịsipareigojimus - sumokejo lietuvių pabėgèliams padėjusioms visuomeninėms organizacijoms, asmenims, nuomojusiems biuro ir atstovų gyvenamąsias patalpas, ir atstovams už darbą.

\section{IŠVADOS}

1. Nuo 1920 m. lapkričio $1 \mathrm{~d}$. iki $1921 \mathrm{~m}$. vasario 9 d. - pirmuoju Komiteto Konstantinopolyje veiklos laikotarpiu - buvo sukurta organizacija, kurios vadovo kpt. B. Blaveščiūno iniciatyva ir organizaciniai gebejjimai padèjo užmegzti ir palaikyti ryšius su Lietuvos vyriausybe, vietos valdžia ir Antantės aukštaisiais komisarais Konstantinopolyje, gauti materialinę paramą lietuvių pabėgèliams ir tremtiniams apgyvendinti, maitinti ir grąžinti ị tèvynę, išduoti tam reikiamus dokumentus. Kpt. B. Blaveščiūno veikla suteikè pagrindą juo pasitikèti ir pavesti jam atstovauti Lietuvos piliečiams Turkijoje.

2. Nuo $1921 \mathrm{~m}$. vasario 9 d. iki 1922 m. kovo 31 d. - antruoju Lietuvos vyriausybės igaliotinio veiklos Turkijoje laikotarpiu, - siekdamas užtikrinti sklandų lietuvių pabėgèlių ir tremtinių grịžimą ị tẻvynę maršrutu Konstantinopolis-Svilengradas-Sofija-Zarebrodas-Belgradas-Zagrebas-Mariboras-Viena-Pasau-Berlynas-Kaunas, kpt. B. Blaveščiūnas išplètojo ir koordinavo paprastąji ir konsulinị lietuvių atstovavimą Balkanų šalyse, taisė padarytas administravimo klaidas ir rūpinosi lèšų paieška lietuvių pabėgèlių ir tremtinių grịžimui finansuoti. Per šị veiklos Turkijoje laikotarpi kpt. B. Blaveščiūnui pavyko sutelkti, pasirūpinti ir grąžinti i 
Lietuvą apie pusę tūkstančio jos piliečių.

3. Atstovavimas Lietuvos piliečių interesams Jugoslavijoje skirstomas i du laikotarpius: pirmą - nuo plk. A. Benjaševičiaus atvykimo (1921 m. vasario mèn.) iki kpt. L. Lippingo paskyrimo (1921 m. gegužès 7 d.) ir antrą - nuo kpt. L. Lippingo paskyrimo iki jo atšaukimo $(1921 \mathrm{~m}$. kovo 16 d.). Plk. A. Benjaševičiui labiau rūpejo atstovavimo finansinè pusè, todèl daug dokumentų išduota ne iš Lietuvos kilusiems asmenims. Kpt. L. Lippingas atsakingai ejo pavestas pareigas - atstovavo Lietuvai ir i tèvynę grižzantiems jos piliečiams Jugoslavijoje.

4. Lietuvių komitetas Sofijoje $1921 \mathrm{~m}$. birželio-1922 m. kovo 21 d., vadovaujamas gen. mjr. A. Golubincevo, atliko komunikacinę ir tarpininkavimo funkciją, persiųsdamas Lietuvos piliečių dokumentus ị Belgradą arba Konstantinopolį, ir talkino per Sofiją grịžtantiems lietuvių pabėgèliams ir į Lietuvą vykstantiems asmenims.

5. Vyr. ltn. J. Macevičius $1921 \mathrm{~m}$. gegužès-rugsèjo mèn. vykdytos misijos metu įvertino konsulinių ịstaigų finansinę būklę ir personalo tinkamumą pareigoms, atliko dokumentacijos patikrą, parèmé pabėgèlius ir pateikè Lietuvos užsienio reikalų ministerijai siūlymus dèl tolesnio Lietuvos konsulinio atstovavimo Turkijoje ir Balkanų šalyse, tačiau Lietuvos vyriausybè, baimindamasi, kad teks apmokèti visų, net ir neteisètai turinčių Lietuvos iggaliotinių išduotus pasus ir liudijimus, grịžimo ì tèvynę išlaidas, delegavo V. Sidzikauską uždaryti Lietuvos konsulines atstovybes Jugoslavijoje ir Turkijoje ir sustabdyti Lietuvių komiteto Sofijoje veiklą.

Iteikta $2016 \mathrm{~m}$. rugsèjo $1 \mathrm{~d}$. 


\title{
LES OFFICIERS LITUANIENS DANS LE SERVICE DIPLOMATIQUE DE LA LITUANIE EN TURQUIE, YOUGOSLAVIE ET BULGARIE (1920-1922)
}

\author{
Prof. dr. Sandra GRIGARAVIČIŪTĖ \\ Université des sciences de l'éducation de Lituanie
}

Le rôle du corps des officiers dans la diplomatie lituanienne (19181922) n’a pas été dévoilé jusquà présent. Les chercheurs ont accordé un peu d'attention uniquement à l'action du colonel Kazys Grinius, du capitaine L. Dymša et du major S. Zaskevičius en 1919-1922. La publication parue en 2016 de Andriejus Stoliarovas « Diplomatie militaire de la République de Lituanie en 1919-1940. Représentants militaires et attachés militaires » devrait donner une impulsion aux recherches dans ce domaine. 1921 et 1922 ont été les années le retour des réfugiés de guerre et des déportés lituaniens de l'ancien Empire russe, d'Europe centrale et orientale, des pays des Balkans et de Turquie. Des représentants spécialement désignés avec des mandats consulaires s'occupaient du retour des réfugiés de guerre et des déportés. Une partie d’entre eux étaient des officiers lituaniens ou des Lituaniens ayant obtenu un grade dofficier dans l'Empire russe.

Lobjectif de létude est d'analyser le processus de constitution et de fonctionnement des comités / conseils lituaniens et des représentations consulaires en Turquie, Yougoslavie et Bulgarie entre le $1^{\text {er }}$ novembre 1920 et le 31 mars 1922, en accordant une attention particulière à laction des officiers présidents et représentants. Létude couvre la période allant de la constitution du comité à Constantinople le $1^{\text {er }}$ novembre 1920 à la révocation du représentant du Gouvernement de la Lituanie en Turquie et la fermeture de la représentation consulaire en Turquie le 31 mars 1922.

La constitution du comité de Constantinople a été déterminée par une concorde entre intérêt public avec les citoyens lituaniens présents en Turquie qui avaient besoin d'une institution représentant leurs intérêts, délivrant des documents reconnus dans les pays européens et s'occupant de 
leur hébergement, l'alimentation, rapatriement et évacuation, et intérêt privé avec les officiers de l'armée de $\mathrm{P}$. Wrangel sans documents leur permettant d'entrer dans les pays européens. Le comité de Constantinople remplissait une fonction de communication en correspondant avec le Gouvernement lituanien, les autorités turques et les hauts commissaires de l'Entente, sociale en soccupant de l'hébergement et de l'alimentation des réfugiés lituaniens, et consulaire en délivrant les documents et défendant les intérêts des citoyens lituaniens.

Le représentant consulaire de la Lituanie en Turquie le capitaine B. Blaveščiūnas du 9 février 1921 au 31 mars 1922 a surtout travaillé à rechercher des moyens pour faire rentrer les Lituaniens via la Bulgarie et la Yougoslavie ou de ces pays et initier dans ces pays à la constitution de comités / conseils, subordonnés au représentant de la Lituanie en Turquie et apportant une assistance sociale et consulaire aux citoyens lituaniens. Président du conseil des citoyens de la République de Lituanie à Belgrade puis, plus tard, représentant, le capitaine L. Lippingas délivrait les passeports et les visas pour les réfugiés se rendant en Lituanie, fournissait des informations sur la Lituanie à la presse de Belgrade et au ministère yougoslave des Affaires étrangères, et établissait des relations avec les représentants des autres pays à Belgrade.

Lors de sa mission de cinq mois (mai-septembre 1921) en Yougoslavie et en Turquie, le lieutenant chef Juozas Macevičius a rempli les fonctions qui lui avaient été confiés dans ses instructions : il a réalisé les changements de personnel en limogeant les personnes compromises qui travaillaient à la représentation consulaire de la Lituanie en Turquie et en confirmant la nomination par le capitaine B. Blaveščiūnas du capitaine L. Lippingas comme représentant du Gouvernement lituanien à Belgrade, il a constitué un registre des passeports et visas délivrés et, après l'évaluation de la situation financière des employés, il a préparé et envoyé au ministère une estimation du coût des postes des représentations consulaires de la Lituanie à Constantinople et Belgrade, il a subvenu aux besoins des réfugiés et payé une partie des dettes du représentant du Gouvernement lituanien en Turquie pour la location du bureau et l'hébergement des réfugiés en foyer.

Lors de sa mission (12-31 mars 1922), V. Sidzikauskas a rapidement réglé tous les problèmes concernant la représentation consulaire de la 
Lituanie en Turquie, Yougoslavie et Bulgarie : en premier lieu, il a tout d'abord annulé les passeports délivrés à des citoyens non lituaniens ; en deuxième lieu, en les remerciant de sêtre occupé du retour des citoyens lituaniens dans leur pays, il a révoqué les représentants du Gouvernement lituanien à Constantinople et Belgrade, il a interdit au major-général A. Golubincevas de remplir toute fonction en lien avec la représentation des citoyens lituaniens et il a transféré la protection des citoyens lituaniens dans ces pays à la représentation de la Lituanie en Suisse ; en troisième lieu, il a rempli les engagements financiers pris par les représentants du Gouvernement lituanien en payant pour leur travail les organisations publiques qui ont aidé les réfugiés lituaniens, les personnes louant le bureau et le domicile des représentants ainsi que les représentants eux-mêmes. 


\title{
LITHUANIAN OFFICERS IN THE LITHUANIAN DIPLOMATIC SERVICE IN TURKEY, YUGOSLAVIA AND BULGARIA (1920-1922)
}

\author{
Prof. Dr. Sandra GRIGARAVIČIŪTĖ \\ Lithuanian University of Educational Sciences
}

The role of military officers in Lithuanian diplomacy (1918-1922) has not been disclosed until now. Modest attention was paid by researchers only to Colonel Kazys Grinius, Captain L. Dymša, and Major S. Zaskevičius and their activities in 1919-1922. The information journal 'Military diplomacy of the Republic of Lithuania in 1919-1940. Military representatives and the military attaché, which was published in 2016 and completed by Andriejus Stoliarovas should provide impetus for research in this area. The period 1921-1922 saw the return of Lithuanian refugees and exiles from the former Russian Empire, western and central Europe, the Balkan countries, and Turkey. Specially appointed delegates, who had consular powers, took care of the return of refugees and exiles. Some of them were Lithuanian officers and Lithuanians who obtained the rank of officer in the Russian Empire.

The aim of the study is to analyse the process for establishing the Lithuanian committees / councils and consular missions in Turkey, Yugoslavia and Bulgaria, and their functioning on 1 November 1920-31 March 1922 by paying particular attention to the activities of committee chairs and commissioners-officers. The study covers the period from 1 November 1920, the establishment of the Committee in Constantinople, to 31 March 1922, the termination of the Lithuanian Government's Representative in Turkey and the closing of the Lithuanian consular mission in Turkey.

The establishment of the Committee in Constantinople was the result of harmony of the public interest - the Lithuanian citizens who were in Turkey needed a body representing their interests that could issue documents recognized by European countries and provide them with accom- 
modation, food, repatriation and re-evacuation services, and of the private interest - officers of the P. Wrangell army did not have documents which would allow them to enter European countries. The Committee in Constantinople performed the following functions: communicative - to make contact with the Lithuanian government, the government of Turkey and the Entente chief commissioners, social - to take care of Lithuanian refugees' board and lodging, and consular - to issue the documents and protect the interests of Lithuanian citizens.

The consular representative of Lithuania in Turkey, Captain B. Blaveščiūnas, between 9 June 1921 and 31 March 1922 mainly searched for ways to return Lithuanians via Bulgaria and Yugoslavia or from these countries, and initiated the establishment of subordinate committees / councils for the Lithuanian Representative in Turkey to provide social and consular assistance to Lithuanian citizens. The Chairman of the Board of Lithuanian citizens based in Belgrade, and later, the Representative, Captain L. Lipping, issued passports and visas to refugees who travelled to Lithuania, provided information about Lithuania to the Belgrade press and the Yugoslav Ministry of Foreign Affairs, and established ties with representatives of other countries in Belgrade.

Senior Lieutenant Juozas Macevičius during the mission of five months (from May to September 1921) in Yugoslavia and Turkey performed the functions assigned to it under instructions: carried out personnel changes and dismissed compromised persons who worked in the Lithuanian consular representation in Turkey and confirmed Captain L. Lipping as the Representative of the Lithuanian Government in Belgrade appointed by Captain B. Blaveščiūnas, checked the issuance of passports and visas, and having assessed the financial position of officials prepared the estimate for the costs of posts of Lithuanian consular missions in Constantinople and Belgrade and sent it to the Ministry of Lithuania, supported the refugees and paid some of the costs for the rental of the office in Turkey for the Lithuanian Government's representative and for the maintenance of refugees in the dormitory.

V. Sidzikauskas during the mission (12-31 March 1922) promptly solved all the problems related to the Lithuanian consular representation in Turkey, Yugoslavia and Bulgaria. First, he cancelled the passports is- 
sued to non-Lithuanian citizens; second, having thanked them for their concern for Lithuanian citizens returning to their homeland, he rescinded the appointments of the Lithuanian Government's representatives in Constantinople and Belgrade, and banned Brigadier General A. Golubincevas from performing any functions related to the representation of Lithuanian citizens, and transferred custody of Lithuanian citizens in those countries to the Lithuanian mission in Switzerland; third, he fulfilled the financial commitments assumed by the Lithuanian Government's representatives and paid public organizations, which helped Lithuanian refugees, persons who rented office premises and living space for representatives, as well as representatives for their work. 